\title{
Quality control of CarboEurope flux data - Part 1: Coupling footprint analyses with flux data quality assessment to evaluate sites in forest ecosystems
}

\author{
M. Göckede ${ }^{1, *}$, T. Foken ${ }^{1}$, M. Aubinet ${ }^{2}$, M. Aurela ${ }^{3}$, J. Banza ${ }^{4}$, C. Bernhofer ${ }^{5}$, J. M. Bonnefond ${ }^{6}$, Y. Brunet ${ }^{6}$, \\ A. Carrara ${ }^{7}$, R. Clement ${ }^{8}$, E. Dellwik ${ }^{9}$, J. Elbers ${ }^{10}$, W. Eugster ${ }^{11}$, J. Fuhrer ${ }^{12}$, A. Granier ${ }^{13}$, T. Grünwald ${ }^{5}$, \\ B. Heinesch ${ }^{2}$, I. A. Janssens ${ }^{14}$, A. Knohl ${ }^{15,16}$, R. Koeble ${ }^{17}$, T. Laurila ${ }^{3}$, B. Longdoz ${ }^{13}$, G. Manca ${ }^{17}$, M. Marek ${ }^{18}$, \\ T. Markkanen ${ }^{1,19}$, J. Mateus ${ }^{20}$, G. Matteucci ${ }^{21}$, M. Mauder ${ }^{1, * *}$, M. Migliavacca ${ }^{22}$, S. Minerbi ${ }^{23}$, J. Moncrieff ${ }^{8}$, \\ L. Montagnani ${ }^{23}$, E. Moors ${ }^{10}$, J.-M. Ourcival ${ }^{24}$, D. Papale ${ }^{25}$, J. Pereira ${ }^{26}$, K. Pilegaard ${ }^{9}$, G. Pita ${ }^{20}$, S. Rambal ${ }^{24}$, \\ C. Rebmann ${ }^{15}$, A. Rodrigues $^{27}$, E. Rotenberg ${ }^{28}$, M. J. Sanz ${ }^{7}$, P. Sedlak ${ }^{29}$, G. Seufert ${ }^{17}$, L. Siebicke ${ }^{1}$, J. F. Soussana ${ }^{30}$, \\ R. Valentini ${ }^{25}$, T. Vesala ${ }^{19}$, H. Verbeeck ${ }^{14, * *}$, and D. Yakir $^{28}$ \\ ${ }^{1}$ University of Bayreuth, Dept. of Micrometeorology, Bayreuth, Germany \\ ${ }^{2}$ University of Agricultural Sciences, Unit of Biosystems Physic, Gembloux, Belgium \\ ${ }^{3}$ Finnish Meteorological Institute, Helsinki, Finland \\ ${ }^{4}$ University of Evora, Evora, Portugal \\ ${ }^{5}$ Technische Universität Dresden, Inst. of Hydrology and Meteorology, Dept. of Meteorology, Tharandt, Germany \\ ${ }^{6}$ INRA, EPHYSE, Bordeaux, France \\ ${ }^{7}$ Foundation CEAM, Valencia, Spain \\ ${ }^{8}$ University of Edinburgh, School of GeoSciences, Edinburgh, UK \\ ${ }^{9}$ Technical University of Denmark, Risø National Laboratory, Roskilde, Denmark \\ ${ }^{10}$ Alterra, Wageningen, The Netherlands \\ ${ }^{11}$ ETH Zurich, Institute of Plant Sciences, Zurich, Switzerland \\ ${ }^{12}$ Agroscope Research Station ART, Air Pollution/Climate Group, Zurich, Switzerland \\ ${ }^{13}$ INRA, Centre INRA Nancy, UMR1137 Ecologie et Ecophysiologie Forestières, Champenoux, France \\ ${ }^{14}$ University of Antwerpen, Dept. of Biology, Research Group of Plant and Vegetation Ecology, Wilrijk, Belgium \\ ${ }^{15}$ Max Planck Institute for Biogeochemistry, Jena, Germany \\ ${ }^{16}$ ETH Zurich, Institute of Plant Sciences, Zurich, Switzerland \\ ${ }^{17} \mathrm{JRC}$, Inst. for Environment and Sustainability, Ispra, Italy \\ ${ }^{18}$ Institute of Systems Biology and Ecology AS CR, České Budějovice, Czech Republic \\ ${ }^{19}$ University of Helsinki, Dept. of Physical Sciences, Helsinki, Finland \\ ${ }^{20}$ Instituto Superior Tecnico, Lisbon, Portugal \\ ${ }^{21}$ CNR-ISAFOM, Institute for Mediterranean Agricultural and Forest Systems, Rende, Italy \\ ${ }^{22}$ Remote Sensing of Environmental Dynamics Lab., DISAT-UNIMIB, Milan, Italy \\ ${ }^{23}$ Forest Department, Agency for the Environment, Autonomous Province of Bolzano-South Tyrol, Italy \\ ${ }^{24}$ INRA, DREAM CEFE-CNRS, Montpellier, France \\ ${ }^{25}$ University of Tuscia, Dept. of Forest Environment and Resources, Viterbo, Italy \\ ${ }^{26}$ Instituto Superior de Agronomia, Lisbon, Portugal \\ ${ }^{27}$ Estação Florestal Nacional, Oeiras, Portugal \\ ${ }^{28}$ Weizman Institute of Science, Dept. of Environmental Sciences and Energy Research, Rehovol, Israel \\ ${ }^{29}$ Institute of Atmospheric Physics AS CR, Praha, Czech Republic \\ ${ }^{30}$ INRA, Institut National de la Recherche Agronomique, Paris, France \\ *now at: Oregon State University, Dept. of Forest Science, Corvallis, USA \\ *** now at: Agriculture and Agri-Food Canada, Research Branch, Ottawa, Canada \\ *** now at: Laboratory of Climate Sciences and the Environment (LSCE), Joint Unit of CEA-CNRS, Gif-sur-Yvette, France
}

Received: 27 September 2007 - Published in Biogeosciences Discuss.: 9 November 2007

Revised: 21 February 2008 - Accepted: 27 February 2008 - Published: 26 March 2008

Published by Copernicus Publications on behalf of the European Geosciences Union. 
Abstract. We applied a site evaluation approach combining Lagrangian Stochastic footprint modeling with a quality assessment approach for eddy-covariance data to 25 forested sites of the CarboEurope-IP network. The analysis addresses the spatial representativeness of the flux measurements, instrumental effects on data quality, spatial patterns in the data quality, and the performance of the coordinate rotation method. Our findings demonstrate that application of a footprint filter could strengthen the CarboEurope-IP flux database, since only one third of the sites is situated in truly homogeneous terrain. Almost half of the sites experience a significant reduction in eddy-covariance data quality under certain conditions, though these effects are mostly constricted to a small portion of the dataset. Reductions in data quality of the sensible heat flux are mostly induced by characteristics of the surrounding terrain, while the latent heat flux is subject to instrumentation-related problems. The Planar-Fit coordinate rotation proved to be a reliable tool for the majority of the sites using only a single set of rotation angles. Overall, we found a high average data quality for the CarboEurope-IP network, with good representativeness of the measurement data for the specified target land cover types.

\section{Introduction}

Continuous monitoring of fluxes between biosphere and atmosphere using the eddy-covariance technique (e.g. Aubinet et al., 2000; Baldocchi et al., 2000) has become an important tool to improve understanding of the role of different types of ecosystems as sources or sinks for greenhouse gases, with a particular focus on $\mathrm{CO}_{2}$. Datasets gathered by extensive networks such as FLUXNET (Baldocchi et al., 2001), CarboEurope (Valentini et al., 2000) and Ameriflux (Law, 2005) allow studying detailed ecosystem functions across biomes (e.g. Law et al., 2002; Hibbard et al., 2005; Reichstein et al., 2007b; Yuan et al., 2007) and ecosystem responses to climate anomalies and interannual variability (e.g. Wilson et al., 2002; Ciais et al., 2005; Reichstein et al., 2007a), or conducting inverse modeling studies to constrain carbon fluxes (e.g. Gerbig et al., 2003; Wang et al., 2007). Theoretical assumptions restrict the application of the eddy-covariance technique to conditions that often cannot be strictly observed (e.g. Kaimal and Finnigan, 1994; Lee et al., 2004; Foken, 2006), especially at sites placed in topographically challenging terrain or surrounded by a heterogeneous land cover structure. Therefore, to ensure provision of high quality data for the growing community of flux data users, sophisticated protocols for the processing of eddy-covariance measurements (e.g. Mauder et al., 2006; Papale et al., 2006;

Correspondence to: M. Göckede (mathias.goeckede@oregonstate.edu)
Mauder et al., 2007) as well as for quality assessment and quality control (QA/QC, e.g. Foken et al., 2004) have been established.

In most of the studies using eddy-covariance databases on regional to continental scales, each site of the network is used to represent a certain biome type. Since for most sites the scale of horizontal variation is $1 \mathrm{~km}$ or less (e.g. Schmid, 2002), a distance that will often be exceeded by the fetch of the flux measurements (e.g. Jegede and Foken, 1999), footprint analyses (e.g. Schuepp et al., 1990; Horst and Weil, 1994; Schmid, 1994; Leclerc et al., 1997; Rannik et al., 2000; Kljun et al., 2002) have to be performed to test under which conditions the assumption of spatial representativeness is valid. It has been demonstrated that landscape heterogeneity has a significant impact on measurement and interpretation of atmospheric data at a single point in space. Panin et al. (1998) and Panin and Tetzlaff (1999) related energy balance closure problems due to underestimation of turbulent fluxes to length scales of landscape inhomogeneity. Schmid and Lloyd (1999) showed potential errors in flux measurements over inhomogeneous terrain due to non-representative footprints, a sensor location bias that had to be taken into account to derive ecosystem scale fluxes from local measurements. In a modeling study, Baldocchi et al. (2005) demonstrated that subgrid scale heterogeneity can alter landscape scale fluxes by up to $300 \%$. Kim et al. (2006) demonstrated the value of flux footprints to scale up flux data from local to landscape scales in order to link terrestrial observations to remote sensing data. Göckede et al. (2004) combined a flux data quality assessment approach (Foken et al., 2004) with analytic footprint modeling (Schmid, 1994, 1997) to identify correlations between flux data quality and characteristics of the terrain surrounding the flux site. Their approach was successfully applied by Rebmann et al. (2005) on 18 forest sites of the CARBOEUROFLUX network.

This study presents an update of the study by Rebmann et al. (2005), extending the work to the larger number of 25 CarboEurope-IP sites, which cover a wide range of forest ecosystems, climate zones, and management regimes. The original site evaluation approach (Göckede et al., 2004) has been replaced here by an improved version (Göckede et al., 2006) that builds on a more sophisticated Lagrangian Stochastic footprint algorithm (Rannik et al., 2000, 2003) and a more realistic approach to obtain areally-averaged surface roughness lengths (Hasager and Jensen, 1999) as input for the model. The extended site evaluation scheme includes (i) a quality assessment of the eddy-covariance fluxes and spatial structures in data quality, (ii) analysis of the spatial representativeness in terms of land cover structure and (iii) assessment of the performance of the applied Planar-Fit coordinate rotation procedure (Wilczak et al., 2001). Combination of these measures identifies potential problems connected to terrain characteristics and instrumental setup that reduce data quality. Including these findings as quality flags into eddy-covariance databases strengthens data reliability, 
Table 1. List of CarboEurope-IP sites participating in this study. Please refer to the site archive on the CarboData webpage (http://gaia. agraria.unitus.it/database/Sites.asp) for more detailed information.

\begin{tabular}{|c|c|c|c|c|}
\hline Site Code & Site name & Location & $\begin{array}{c}\text { Elevation } \\
\text { [m a.s.1.] }\end{array}$ & Dominant species \\
\hline BE-Vie & Vielsalm & $50^{\circ} 18^{\prime} \mathrm{N}, 06^{\circ} 00^{\prime} \mathrm{E}$ & 450 & Fagus sylvatica, Pseudotsuga menziesii \\
\hline BE-Bra & Brasschaat & $51^{\circ} 18^{\prime} \mathrm{N}, 04^{\circ} 31^{\prime} \mathrm{E}$ & 16 & Pinus sylvestris, Quercus robur \\
\hline CZ-BK1 & Bily Kriz & $49^{\circ} 30^{\prime} \mathrm{N}, 18^{\circ} 32^{\prime} \mathrm{E}$ & 898 & Picea abies \\
\hline CH-Lae & Laegeren & $47^{\circ} 28^{\prime} \mathrm{N}, 08^{\circ} 22^{\prime} \mathrm{E}$ & 682 & Fagus sylvatica, Picea abies \\
\hline DE-Hai & Hainich & $51^{\circ} 04^{\prime} \mathrm{N}, 10^{\circ} 27^{\prime} \mathrm{E}$ & 438 & Fagus sylvatica \\
\hline DE-Tha & Tharandt & $50^{\circ} 58^{\prime} \mathrm{N}, 13^{\circ} 34^{\prime} \mathrm{E}$ & 380 & Picea abies \\
\hline DE-Wei & Weidenbrunnen & $50^{\circ} 09^{\prime} \mathrm{N}, 11^{\circ} 52^{\prime} \mathrm{E}$ & 775 & Picea abies \\
\hline DE-Wet & Wetzstein & $50^{\circ} 27^{\prime} \mathrm{N}, 11^{\circ} 27^{\prime} \mathrm{E}$ & 792 & Picea abies \\
\hline DK-Sor & Sorø & $55^{\circ} 29^{\prime} \mathrm{N}, 11^{\circ} 38^{\prime} \mathrm{E}$ & 40 & Fagus sylvatica \\
\hline ES-LMa & Las Majadas & $39^{\circ} 57^{\prime} \mathrm{N}, 05^{\circ} 47^{\prime} \mathrm{W}$ & 265 & Quercus ilex \\
\hline FI-Hyy & Hyytiälä & $61^{\circ} 51^{\prime} \mathrm{N}, 24^{\circ} 17^{\prime} \mathrm{E}$ & 181 & Pinus sylvestris, Picea abies \\
\hline FI-Sod & Sodankylä & $67^{\circ} 22^{\prime} \mathrm{N}, 26^{\circ} 38^{\prime} \mathrm{E}$ & 179 & Pinus sylvestris \\
\hline FR-Hes & Hesse & $48^{\circ} 40^{\prime} \mathrm{N}, 07^{\circ} 04^{\prime} \mathrm{E}$ & 300 & Fagus sylvatica \\
\hline FR-LBr & Le Bray & $44^{\circ} 43^{\prime} \mathrm{N}, 00^{\circ} 46^{\prime} \mathrm{W}$ & 62 & Pinus pinaster \\
\hline FR-Pue & Puechabon & $43^{\circ} 44^{\prime} \mathrm{N}, 03^{\circ} 36^{\prime} \mathrm{E}$ & 270 & Quercus ilex \\
\hline IL-Yat & Yatir & $31^{\circ} 20^{\prime} \mathrm{N}, 35^{\circ} 03^{\prime} \mathrm{E}$ & 630 & Pinus halepensis \\
\hline IT-Col & Collelongo & $41^{\circ} 51^{\prime} \mathrm{N}, 13^{\circ} 35^{\prime} \mathrm{E}$ & 1550 & Fagus sylvatica \\
\hline IT-Ren & Renon & $46^{\circ} 35^{\prime} \mathrm{N}, 11^{\circ} 26^{\prime} \mathrm{E}$ & 1735 & Picea abies \\
\hline IT-Ro1 & Roccarespampani & $42^{\circ} 23^{\prime} \mathrm{N}, 11^{\circ} 51^{\prime} \mathrm{E}$ & 120 & Quercus cerris \\
\hline IT-PT1 & Parco Ticino & $45^{\circ} 12^{\prime} \mathrm{N}, 09^{\circ} 04^{\prime} \mathrm{E}$ & 65 & Populus X Euroamericana (Clone I-214) \\
\hline IT-SRo & San Rossore & $43^{\circ} 44^{\prime} \mathrm{N}, 10^{\circ} 17^{\prime} \mathrm{E}$ & 4 & Pinus pinaster \\
\hline NL-Loo & Loobos & $52^{\circ} 10^{\prime} \mathrm{N}, 05^{\circ} 45^{\prime} \mathrm{E}$ & 25 & Pinus sylvestris \\
\hline PT-Esp & Espirra & $38^{\circ} 38^{\prime} \mathrm{N}, 08^{\circ} 36^{\prime} \mathrm{W}$ & 95 & Eucalyptus globulus \\
\hline PT-Mi1 & Mitra II & $38^{\circ} 32^{\prime} \mathrm{N}, 08^{\circ} 00^{\prime} \mathrm{W}$ & 220 & Quercus ilex, Quercus suber \\
\hline UK-Gri & Griffin & $56^{\circ} 37^{\prime} \mathrm{N}, 03^{\circ} 48^{\prime} \mathrm{W}$ & 340 & Picea sitchensis \\
\hline
\end{tabular}

allowing the user community to filter out measurements that do not meet the standards required for their specific studies.

\section{Data}

A total of 25 forested flux measurement sites of the CarboEurope-IP network were analyzed in the context of this study. Site names and main characteristics are listed in Table 1. Flux data processing for all participating sites followed the concept proposed by Aubinet et al. (2000), which has been further refined by Mauder et al. (2006, 2007). Original flow fields were rotated according to the planar fit method (Wilczak et al., 2001), and subsequently the Moore- (Moore, 1986), Schotanus- (Liu et al., 2001), and WPL-corrections (Webb et al., 1980) were performed. The flux data quality assessment is described in detail in Sect. 3.3. No friction velocity threshold ( $u_{*}$ criterion) was applied to filter out measurements with low turbulence intensities.

For the 25 sites that participated in this study, on average three months of flux data (minimum two months, maximum five months, Table 2) were provided (76 months of total raw data). The majority of the data (93\%, or 71 months) was sent as raw data files by the cooperating research teams and uniformly processed with the flux processing software at the University of Bayreuth (TK2, Mauder et al., 2008). At the two sites that provided processed fluxes instead of eddycovariance raw data for this study, data processing protocols exactly matched that of the TK2, ensuring a uniform data processing for the entire study. The average data loss due to gaps in the raw data was $9.2 \%$ (minimum $0.3 \%$, maximum $37.6 \%)$. For the majority of the sites (14), the data loss due to gaps was below $5 \%$.

24 out of the 25 participating sites provided the land cover maps required to analyze the spatial representativeness of the eddy-covariance fluxes (for $\mathrm{CH}$-Lae, the land cover map was not compatible with the format needed for this analysis). These maps had a mean grid resolution of $40 \mathrm{~m}$ (minimum $10 \mathrm{~m}$, maximum $150 \mathrm{~m}$ ) and an averaged number of land cover classes of 10 (minimum 2 , maximum 34 ). See Table 2 for details. The impact of these differences on the site evaluation results presented herein are discussed in Sect. 5. 
Table 2. Information on data material provided by the participating CarboEurope-IP sites.

\begin{tabular}{cccccc}
\hline Site Code & Data time period & $\begin{array}{c}\text { Data } \\
\text { months }\end{array}$ & $\begin{array}{c}\text { Data gaps } \\
{[\%]}\end{array}$ & $\begin{array}{c}\text { Map } \\
\text { resolution [m] }\end{array}$ & $\begin{array}{c}\text { Landuse } \\
\text { classes }\end{array}$ \\
\hline BE-Vie & 1 Mar-31 May 2002 & 3 & 2.3 & 50 & 4 \\
BE-Bra & 2 May-12 Aug 2001 & 3.5 & 13.1 & 150 & 3 \\
CZ-BK1 & 1 Jun-28 Aug 2004 & 3 & 0.6 & 100 & 3 \\
CH-Lae & 31 May-1 Sep 2004 & 3 & 2 & - & - \\
DE-Hai & 26 Apr-3 Aug 2003 & 3.25 & 1 & 30 & 11 \\
DE-Tha & 1 May-30 Sep 2004 & 5 & 1.3 & 25 & 17 \\
DE-Wei & 21 May-1 Aug 2003 & 2.33 & 2.2 & 15 & 10 \\
DE-Wet & 1 Jun-3 Sep 2003 & 3 & 1.2 & 20 & 2 \\
DK-Sor & 10 Jun-25 Aug 2002 & 3.5 & 9.2 & 25 & 19 \\
ES-LMa & 5 Apr-31 Jul 2004 & 4 & 16 & 40 & 7 \\
FI-Hyy & 1 Jun-31 Aug 2003 & 3 & 4.3 & 25 & 8 \\
FI-Sod & 30 May-31 Aug 2004 & 3 & 13.7 & 25 & 34 \\
FR-Hes & 1 May-31 Jul 2003 & 3 & 3.6 & 20 & 7 \\
FR-LBr & 1 Jun-19 Aug 2004 & 2.66 & 0.3 & 20 & 12 \\
FR-Pue & 1 May-8 Jul 2004 & 2.25 & 8.8 & 30 & 4 \\
IL-Yat & 1 Jan-30 Apr 2004 & 4 & 21.6 & 30 & 13 \\
IT-Col & 15 Jun-15 Sep 2001 & 3 & 24 & 10 & 2 \\
IT-Ren & 19 Jun-17 Aug 2004 & 2 & 2.2 & 100 & 2 \\
IT-Ro1 & 1 Jun-28 Aug 2004 & 3 & 27 & 10 & 5 \\
IT-PT1 & 31 May-31 Aug 2004 & 3 & 2.9 & 15 & 19 \\
IT-SRo & 1 May-30 Jun 2004 & 2 & 1 & 25 & 23 \\
NL-Loo & 1 Jun-31 Jul 2003 & 2 & 1.1 & 100 & 6 \\
PT-Esp & 6 Jul-29 Nov 2004 & 5 & 10.5 & 40 & 19 \\
PT-Mi1 & 3 Mar-18 May 2006 & 2.5 & 21.6 & 10 & 5 \\
UK-Gri & 21 Oct-25 Dec 2004 & 2 & 37.6 & 50 & 4 \\
\hline
\end{tabular}

\section{Site characterization methodology}

\subsection{Source area analysis}

The footprint algorithm applied for this study builds on the Thomson (1987) LS trajectory model of Langevin type (e.g. Wilson et al., 1983; Wilson and Sawford, 1996), which is operated forward in time. The exact formulation of the footprint algorithms, the definition of the flow statistics and the effect of stability on the profiles is described in Rannik et al. (2003). For each model run, $5 \times 10^{4}$ particles were released from a height equal to 0.01 times the canopy height. A flux footprint can be derived by integrating their trajectories up to the upwind distance accounting for approximately $90 \%$ of the total flux. To enable footprint analyses based on 30-min averaged fluxes over periods of months for a large number of sites, source weight functions were pre-calculated and stored for more than 10000 different combinations of measurement height, roughness length and atmospheric stability.

Each 30-min source weight function is projected onto a discrete grid representing the area surrounding the flux tower, with the assigned weighting factors representing the influence of each grid cell to the actual measurement. For each of these grid cells the land cover type has been defined, so that the land cover composition for the specific measurement can be obtained by summing up the weighting factors sorted by land cover. In a similar manner, quality flags for the eddycovariance fluxes (see Sect. 3.3) are projected into the area and stored in a database. An overall quality flag per cell can be determined statistically after the complete observation period has been processed (see Göckede et al., 2004, 2006, for details), and based on these statistics maps of flux data quality can be produced. The quality measures analyzed in this study are the QA/QC flags for momentum flux, sensible heat flux, latent heat flux, $\mathrm{CO}_{2}$ flux, and the mean values of the vertical wind component before and after performing the Planar-Fit rotation (Wilczak et al., 2001). Summing up all 30-min source weight functions yields the relative influence of each part of the surrounding terrain to the fluxes measured, the so-called footprint climatology (Amiro, 1998). These concepts of linking footprint results with flux data attributes are described in detail in Göckede et al. $(2004,2006)$. 
3.2 Evaluation of land cover composition within the footprint

The evaluation of the land cover composition within the footprint of the measurements is a centerpiece of this study. Each of the sites in networks such as CarboEurope-IP has been set up to monitor a specific type of land cover, or a combination of two or more land cover types, respectively. Flux contributions from different land cover types than the specified target introduce a systematic bias to the measurements, altering the "true" signal from the target land cover type and thus increasing the scatter in biome intercomparison studies. Therefore, the source area of the fluxes measured has to be known to evaluate how well the measurements represent the specified target land cover. The approach presented herein determines the overall representativeness of a site with respect to the specified target land cover type, and identifies possible problematic wind sectors or meteorological situations that fail to produce representative data.

For each of the 30-min averaged fluxes of a processed dataset, our approach determines the flux contribution of the specified target land cover type, and the results are transferred to a database. Based on this information, individual thresholds for a minimum required flux contribution can be defined for different studies to filter out measurements failing to meet that requirement. After intensive pre-analyses, we found the following classification into four groups the most practicable to characterize individual 30-min measurements and facilitate the overall site evaluation:

- Homogeneous measurements: $95 \%$ or more of the flux are emitted by the specified target land cover type. Systematic bias by flux contributions from other land cover types is negligible. Sites with a high percentage of homogeneous measurements reliably represent their specified target land cover type, and are thus ideal for acrossbiome studies.

- Representative measurements: 80 to $95 \%$ of the flux are emitted by the target land cover type. We chose the $80 \%$-threshold to limit possible disturbing influences of non-target land cover types on the measured fluxes to a low level. At the same time, the threshold is relaxed enough to acknowledge the fact that the vast majority of FLUXNET sites has to deal with heterogeneous land cover structures to a certain degree, and ideal homogeneity in the fetch is very rare.

- Acceptable measurements: 50 to $80 \%$ flux contribution are emitted by the target land cover type. Though still dominant, the fluxes from the target areas are diluted significantly. Use for across-biome studies is not recommended, but may be valid depending on study objectives.

- Disturbed measurements. Less than 50\% flux contribution from the target land cover type. These mea- surements are dominated by flux contributions which, strictly speaking, should be regarded as disturbances. These data are therefore not valid for across-biome studies.

Using the above categories, the sites within a flux network can be grouped according to the usefulness of a footprint filter to assure the representativeness of the measurement data for the specified target land cover type (see Sect. 4.1).

\subsection{Flux data quality assessment}

All fluxes were checked for their quality according to a scheme proposed by Foken and Wichura (1996) in the revised version as presented by Foken et al. (2004). These tests are based on the analysis of high-frequency raw data of vertical and longitudinal wind components, air temperature, and water- and $\mathrm{CO}_{2}$-concentrations. Quality ratings assigned for stationarity of the flow and the development of the turbulent flow field (using the so-called integral turbulence characteristics) are combined to yield the overall quality flag of the data, with individual results for the fluxes of momentum, sensible and latent heat, and $\mathrm{CO}_{2}$. The deviation of the mean vertical wind component from zero forms a separate quality measure.

The stationarity of the flow is tested by comparing 30-min covariances with the linear average of six 5-min covariances obtained for the same period (Foken and Wichura, 1996). Good agreement between both values indicates stationary conditions, e.g. deviations lower than 15 percent are rated with flag 1 (Foken et al., 2004).

Integral turbulence characteristics are based on the fluxvariance similarity (e.g. Obukhov, 1960; Wyngaard et al., 1971), and can be expressed as functions of stability of stratification (Panofsky et al., 1977; Foken et al., 1991) in case of undisturbed turbulence (Kaimal and Finnigan, 1994; Arya, 2001). To use them as a measure of flux data quality, values parameterized with standard functions (Thomas and Foken, 2002) are compared to the measurement results. Close agreement between both values indicates a well developed turbulent flow field, resulting in a good quality rating (e.g. differences are lower than $15 \%$ for class 1). Deviations, which may be caused by disturbances in the turbulent flow field like obstacles in the fetch or flow distortion caused by the instrument setup, are penalized by lower quality flags (differences for class 9 are $>1000 \%$ ). Specifics on the classification are given in Foken et al. (2004). In the study presented, integral turbulence characteristics are only considered for the horizontal and vertical wind components, since for the temperature scalar, the parameterization (Foken et al., 2004) is only valid for unstable stratification, and no valid parameterizations exist for the water vapor and $\mathrm{CO}_{2}$ scalars (see also Rebmann et al., 2005; Göckede et al., 2006).

Details on the combination of the ratings for stationarity and integral turbulence characteristics to form the overall flux quality rating is given in Foken et al. (2004). Quality flags range on a scale from one (best) to nine (worst) to 


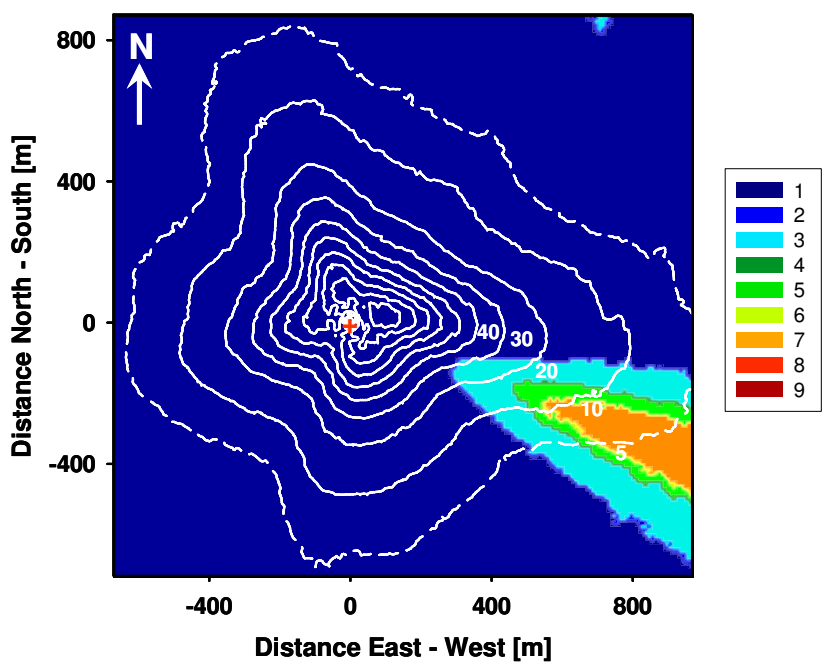

Fig. 1. Quality rating of the momentum flux during stable stratification $(z / L>0.0625 ; z$ : measurement height $[\mathrm{m}] ; L$ : Obukhov length [m]) at the Wetzstein site (DE-Wet). Colors show the median data quality for each grid cell of the terrain matrix (1=best). The three-dimensional accumulated source weight function is indicated by the white lines. Values are in percentages to the peak of the function, with solid lines ranging from $90 \%$ to $10 \%$, and the dashed line as $5 \%$ of the maximum. High values indicate a high relative contribution of the specific area to the fluxes measured in the given observation period. Distances to the tower position (red cross) are given in $[\mathrm{m}]$.

each flux measurement. As a short guideline, fundamental research should be restricted to measurements with the highest data quality (classes one to three), while classes four to six indicate good quality, and data can be used for calculating solid averages or long-term budgets of the exchange fluxes. Classes seven and eight may be included for averaging purposes at the user's discretion, but should be checked with care for plausibility because of significant deviations from the basic theoretical assumptions for the eddy-covariance technique. Measurements rated with quality class nine should be discarded in any case. This classification does not include a test for the presence of advective fluxes, which can act as a large selective systematic error in the measurements and introduce large uncertainties into long-term budgets in addition to small errors in half-hourly measurements.

\subsection{Spatial structures in the data quality flags}

Based on the footprint results, this approach links the quality flags for momentum flux, sensible and latent heat fluxes, and $\mathrm{CO}_{2}$ flux with characteristics of the surrounding terrain. Comparison of spatial structures in the data quality between individual sites is not straightforward, since local terrain characteristics and climate conditions may vary significantly. To facilitate an overall evaluation and allow site intercomparisons, we differentiate between three kinds of spatial effects in the data quality: isolated effects, multidirectional effects and instrumental effects. The abundance of each of those effects can be used for site classification (see Sect. 4.2).

Isolated effects on the data quality consist of a narrow wind sector with reduced data quality in an otherwise highquality region of the map. Usually, due to the restriction to a specific wind direction and stability regime, the total number of lower-quality measurements is rather low, so that they could easily be overlooked if not coupled to footprint results as done in this approach. A perfect example for an isolated effect in the data quality was found for the Wetzstein site (DE-Wet, Fig. 1). This site received an outstanding overall quality rating for all fluxes, except for a narrow wind sector around $110^{\circ}$ where the quality of all four fluxes analyzed was significantly reduced during stable to neutral stratification. In this case, the effect can most probably be attributed to flow distortion induced by the instrumentation setup, as it occurs independent of the type of flux. However, since wind direction from this sector is very rare at the Wetzstein site $(1.8 \%$ for $2002-2006$ for $105-115^{\circ}$ over all stability regimes), this effect does not have a significant impact on the overall site performance.

For multidirectional effects, the median data quality is significantly lower than average for a specific stability of stratification or flux. In contrast to the isolated effect, a reduced data quality is found for several wind sectors, or is observed independent of the wind direction. Multidirectional effects are in most cases caused by instrumentation effects or regional flow patterns, rather than by the local scale characteristics of the surrounding terrain. A very good example for the identification of an multidirectional effect on the data quality was found for the Danish Sorø site (DK-Sor). At Sorø, all fluxes analyzed were of very good overall quality independent of the stability of stratification, except of the latent heat flux during stable stratification (Fig. 2). Since also the $\mathrm{CO}_{2}$ flux was not affected by this reduction in data quality, both terrain influences and general instrumental problems of infra-red gas analyzer (IRGA) or sonic anemometer can be ruled out as a possible cause of the problem. One plausible explanation is that the tubing of the closed-path IRGA system affects water vapor transport to the sensor during nighttime measurements (see also Ibrom et al., 2007), altering the quality of the latent heat flux, but not of the $\mathrm{CO}_{2}$ flux. Other multidirectional effects identified in the context of this study were caused by extreme low turbulence intensities during stable stratification which did not pass the test for a well-developed turbulent flow field (FI-Hyy), or by a regional wind climatology with channeled flow that covered certain wind sectors only during transitional periods with non stationary flow conditions (CH-Lae, ES-LMa).

Instrumental effects are identified by obvious spatial structures in the maps of median data quality that can be correlated to the geometry of the installed sensors. In the context of this study, all such effects found were related to the sonic anemometers, while no general data quality effect could be 

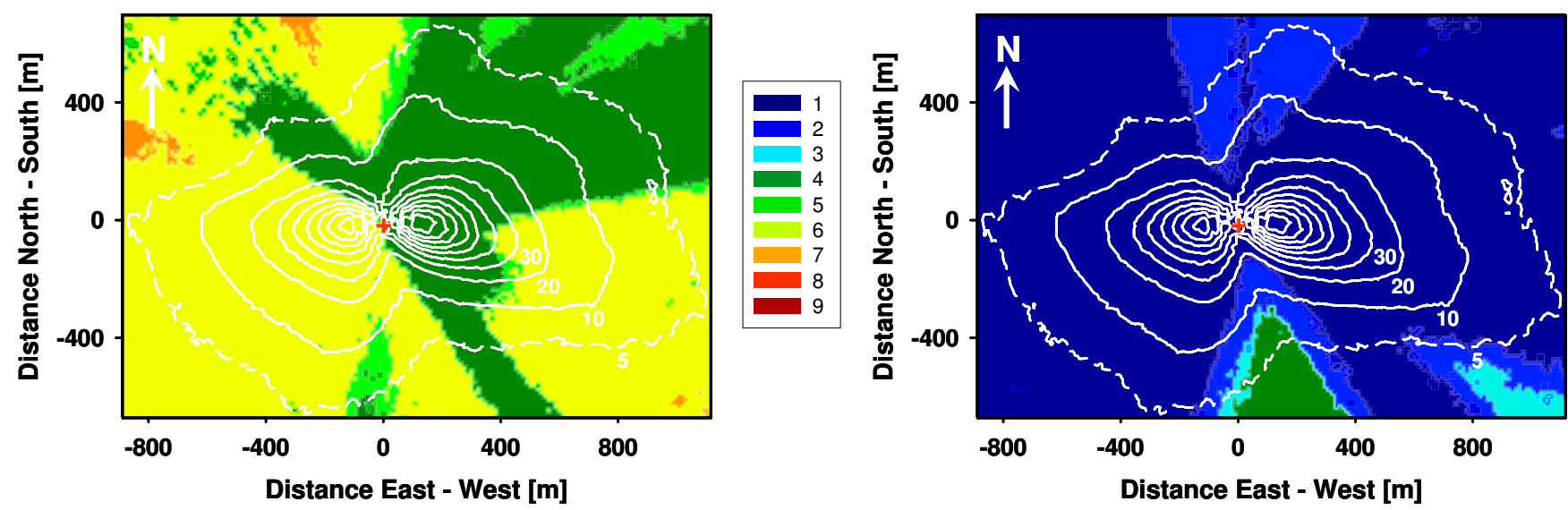

Fig. 2. Comparison of the spatial data quality of the latent heat flux (left panel) and the $\mathrm{CO}_{2}$ flux (right panel) during stable stratification at the Sorø site (DK-Sor). See legend of Fig. 1 for map details.

linked to the IRGAs. As an example, Fig. 3 shows the data quality map for the latent heat flux during stable stratification at Sodankylä (FI-Sod), where a METEK USA1 sonic anemometer is installed. For this site, during stable stratification quality maps for all fluxes were structured into 3 sectors of 120 degrees each, with good data quality in the north, east-southeast and southwest, and a reduced quality in between. These results indicate that there is a flow distortion induced by geometry of the METEK USA1 sensor head, slightly compromising the quality of the measurements.

\subsection{Evaluation of the Planar-Fit coordinate rotation method}

For this study, we applied the Planar-Fit coordinate rotation method (Wilczak et al., 2001) for all sites to adapt the orientation of the measured wind regime to the requirements of eddy-covariance flux data processing (e.g. a mean vertical wind velocity of zero). Only one set of coordinate rotation angles was applied at each site to avoid systematic errors in long-term mass balances introduced by transient horizontal flux divergences below the sensor height for sensors mounted above tall canopies (Finnigan et al., 2003). Consequently, in many cases the rotated mean vertical wind velocity still deviates from the ideal value of zero in some of the wind sectors, because the vertical wind field is often curved instead of being an ideal plane. For a detailed analysis of individual sites, maps of the mean vertical wind velocity before and after rotation can be compared to evaluate the performance of the Planar-Fit method. In the example of the Hesse site (FR-Hes, Fig. 4), the tilted unrotated wind field (maximum mean vertical velocity $0.15 \mathrm{~m} \mathrm{~s}^{-1}$ ) was rotated into a balanced plane with absolute residues below $0.03 \mathrm{~m} \mathrm{~s}^{-1}$. For site intercomparison, the maximum absolute value of the vertical wind velocity after rotation can be used to evaluate the performance of the Planar-Fit coordinate rotation method.

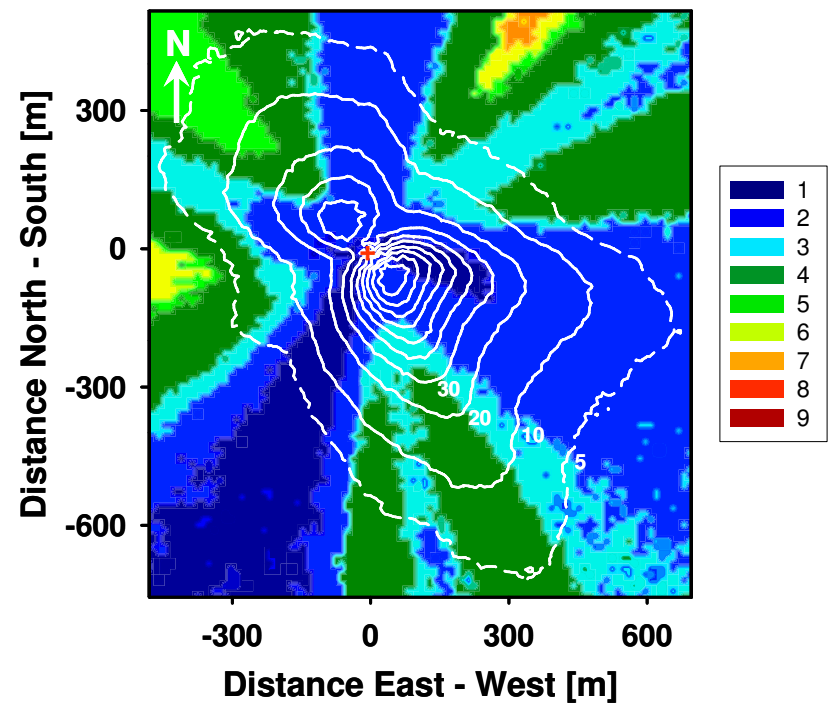

Fig. 3. Quality evaluation of the latent heat flux during stable stratification for the Sodankylä site. See legend of Fig. 1 for map details.

\section{Results for the CarboEurope-IP network}

\subsection{Representativeness for the specified target land cover}

We analyzed the representativeness for the specified land cover type for 24 forested CarboEurope sites. Please note that while the classification of individual 30-min averages follows the scheme proposed in Sect. 3.2, for the overall site evaluation it has to be determined what percentage of the total dataset exceeds one of those thresholds, which can be chosen by the user. Three of those thresholds were tested herein.

The vast majority (for most sites all) of the 30-min measurements analyzed in this study were dominated by flux emitted from the specified target land cover type (flux contribution of a 30-min averaged flux $>50 \%$ ). The maximum 
Table 3. Representativeness results for the specified target land cover type. Values indicate the percentage of 30-min measurements for each site that fall within each of the three categories shown.

\begin{tabular}{ccccc}
\hline Site Code & $\begin{array}{c}>95 \% \text { of flux } \\
\text { from target }\end{array}$ & $\begin{array}{c}>80 \% \text { of flux } \\
\text { from target }\end{array}$ & $\begin{array}{c}>50 \% \text { of flux } \\
\text { from target }\end{array}$ & $\begin{array}{c}\text { Maximum residues of } \\
\text { the mean vertical wind } \\
\text { after Planar-Fit }\end{array}$ \\
\hline BE-Vie & 41.5 & 92.3 & 99.9 & 0.06 \\
BE-Bra & 20.6 & 42.5 & 98.9 & 0.06 \\
CZ-BK1 & 99.7 & 100.0 & 100.0 & 0.02 \\
CH-Lae & - & - & - & 0.20 \\
DE-Hai & 83.5 & 99.9 & 100.0 & 0.03 \\
DE-Tha & 18.4 & 90.5 & 99.9 & 0.08 \\
DE-Wei & 19.0 & 64.0 & 100.0 & 0.04 \\
DE-Wet & 56.9 & 100.0 & 100.0 & 0.06 \\
DK-Sor & 0.0 & 9.5 & 99.3 & 0.05 \\
ES-LMa & 96.3 & 99.9 & 100.0 & 0.04 \\
FI-Hyy & 9.1 & 59.0 & 99.9 & 0.04 \\
FI-Sod & 7.6 & 97.4 & 99.7 & 0.03 \\
FR-Hes & 11.7 & 84.5 & 99.0 & 0.03 \\
FR-LBr & 33.2 & 68.5 & 99.3 & 0.12 \\
FR-Pue & 99.9 & 100.0 & 100.0 & 0.04 \\
IL-Yat & 43.0 & 92.7 & 100.0 & 0.06 \\
IT-Col & 89.9 & 100.0 & 100.0 & 0.06 \\
IT-Ren & 86.6 & 99.9 & 100.0 & 0.10 \\
IT-Ro1 & 0.3 & 86.2 & 99.3 & 0.04 \\
IT-PT1 & 0.1 & 53.7 & 96.7 & 0.06 \\
IT-SRo & 0.0 & 55.9 & 98.0 & 0.02 \\
NL-Loo & 72.8 & 99.9 & 100.0 & 0.03 \\
PT-Esp & 3.6 & 97.6 & 99.7 & 0.02 \\
PT-Mi1 & 99.9 & 100.0 & 100.0 & 0.09 \\
UK-Gri & 99.2 & 100.0 & 100.0 & \\
\hline
\end{tabular}

percentage of measurements with target area flux contributions lower than $50 \%$ in the dataset for an individual site was $3.3 \%$. However, application of this threshold is not suitable for an overall site evaluation, because with a possible $49 \%$ of flux emitted by other sources there is still a significant source of uncertainty that might compromise the representativeness.

Checking for the most rigid quality measure, the test for homogeneous source areas $(95 \%$ or more of the flux is emitted by the target land cover type), we found that 10 of the 24 sites had $50 \%$ or more of their 30-min measurements falling into this category. These sites, which perfectly represent their specified target land cover type, are FR-Pue (99.9\%), PTMi1 (99.9\%), CZ-BK1 (99.7\%), UK-Gri (99.2\%), ES-LMa $(96.3 \%)$, IT-Col $(89.9 \%)$, IT-Ren $(86.6 \%)$, DE-Hai $(83.5 \%)$, NL-Loo $(72.8 \%)$, and DE-Wet $(56.9 \%)$. Values in brackets give the percentage of 30-min measurements with homogeneous source area compositions (see also Table 3 ).

The most suitable threshold defined in Sect. 3.2 to perform an overall site evaluation is the percentage of 30-min measurements exceeding the threshold of $80 \%$ flux contribution from the target land cover type (representative measurements). For a better overview of the results, we grouped the
24 sites into four different categories according to the percentage of representative measurements in the total dataset. See also Table 3 for details.

- 90\% or more of data exceed $80 \%$-threshold: 15 sites (BE-Vie, CZ-BK1, DE-Hai, DE-Tha, DE-Wet, ESLMa, FI-Sod, FR-Pue, IL-Yat, IT-Col, IT-Ren, NL-Loo, PT-Esp, PT-Mi1, UK-Gri). These sites represent their specified target land cover type very well. The measurements could be used without additional footprint filters, as the influence of disturbing heterogeneities is very low. Note that the 10 "homogeneous" sites listed above all have $99.9 \%$ or more of the 30 -min averaged data exceeding the threshold for representative measurements.

- $60 \%$ to $90 \%$ of data exceed $80 \%$ threshold: 4 sites (DE-Wei, FR-Hes, FR-LBr, IT-Ro1). For these sites, a footprint analysis is recommended to filter the data which are provided for the CarboEurope-IP database. With a considerable percentage of measurements not truly representative for the target land cover type, an additional footprint flag indicating the flux 

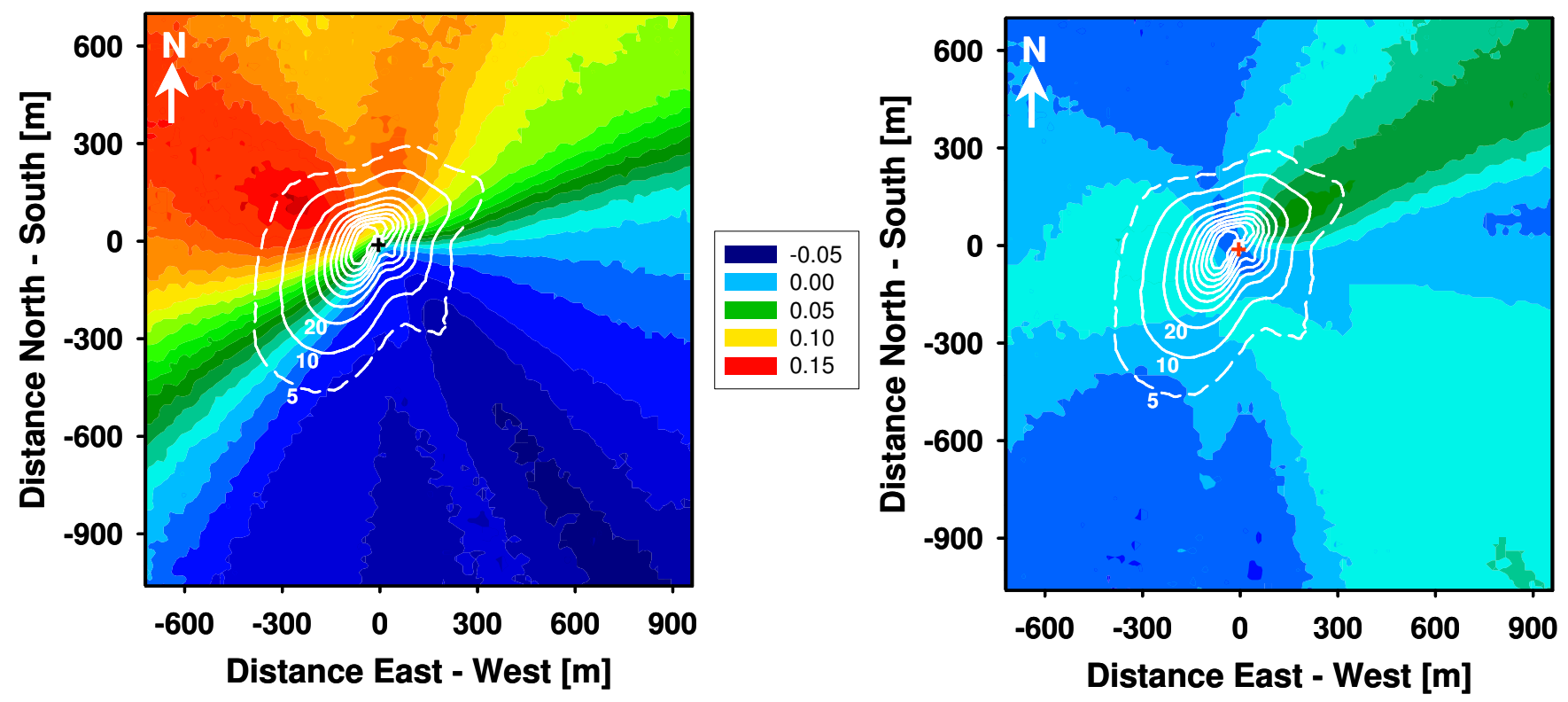

Fig. 4. Mean vertical wind component determined for the Hesse site (FR-Hes) before (left panel) and after (right panel) performing the Planar-Fit coordinate rotation. Colors give the vertical wind component in $\left[\mathrm{m} \mathrm{s}^{-1}\right]$, with the same color scales were used for both graphs.

contribution from the target land cover type will significantly strengthen the data for further use.

- $50 \%$ to $60 \%$ of data exceed the $80 \%$ threshold: 3 sites (FI-Hyy, IT-PT1, IT-SRo). Most measurements are still representative for the target land cover type, but small scale heterogeneities close to the tower that slightly influence the measurements during all stratification cases reduce the flux percentage of the target land cover type. During stable stratification, short fetches in one or several wind sectors lead to a large influence of non-target land cover types. These datasets need a detailed footprint analysis before uploading into the database.

- Less than $50 \%$ of data exceed the $80 \%$ threshold: 2 sites (BE-Bra, DK-Sor). The representativeness of these sites for the specified target land cover types is significantly reduced, due to various reasons. Details on these sites are listed further below.

For Brasschaat (BE-Bra, Fig. 5), the percentage of measurements exceeding the $80 \%$ threshold of flux contribution from the target land cover (forest) is only $42.5 \%$. However, the general situation is similar to the three sites listed in the third category above (50-60\% of representative data), with a small scale heterogeneity close to the tower, but significant reductions of the representativeness only to be found during stable stratification. However, the fetch is extremely short, especially in the main wind direction around the west. Measurements during stable stratification should generally be discarded except for easterly winds. Application of a footprint filter based on the results by Rebmann et al. (2005) at this site increased the contribution of the target vegetation to $>90 \%$ (Nagy et al., 2006). Because stable stratification is predominantly a nighttime phenomenon at this site, the footprint filter strongly affected the nighttime fluxes (on average more than $10 \%$ reduction), while it had virtually no effect on the daytime fluxes.

Two major factors compromise the representativeness of the Sorø (DK-Sor, Fig. 6) data for the target land cover type deciduous forest: First, the deciduous forest is interspersed by a large number of small heterogeneities such as other forest types or grassland patches, and second the fetch is rather short especially in the main wind directions to the east and to the west. Consequently, only $9.5 \%$ of all measurements exceed the threshold of $80 \%$ flux contribution from the target land use type (however, still $99.3 \%$ exceed the threshold of $50 \%$ ). These results have to be interpreted with care, since the wind climatology within the $2 \frac{1}{2}$ month period in summer 2002 used for this study has more pronounced maxima to the east and west than usually found at this site. In addition, most of the large grassland patches, or clearings, within the forest, have characteristics very close to those of the target land cover type deciduous forest. A more representative wind climatology and inclusion of the clearings into the target area would lead to a significant increase of measurements truly representative for the specified target land cover type. Since the quite detailed land cover map provided for this site may have biased the results, a different treatment of the land cover data may change the representativeness of the flux data significantly. The footprint issue for this site has previously been dealt with by Dellwik and Jensen $(2000,2005)$. 

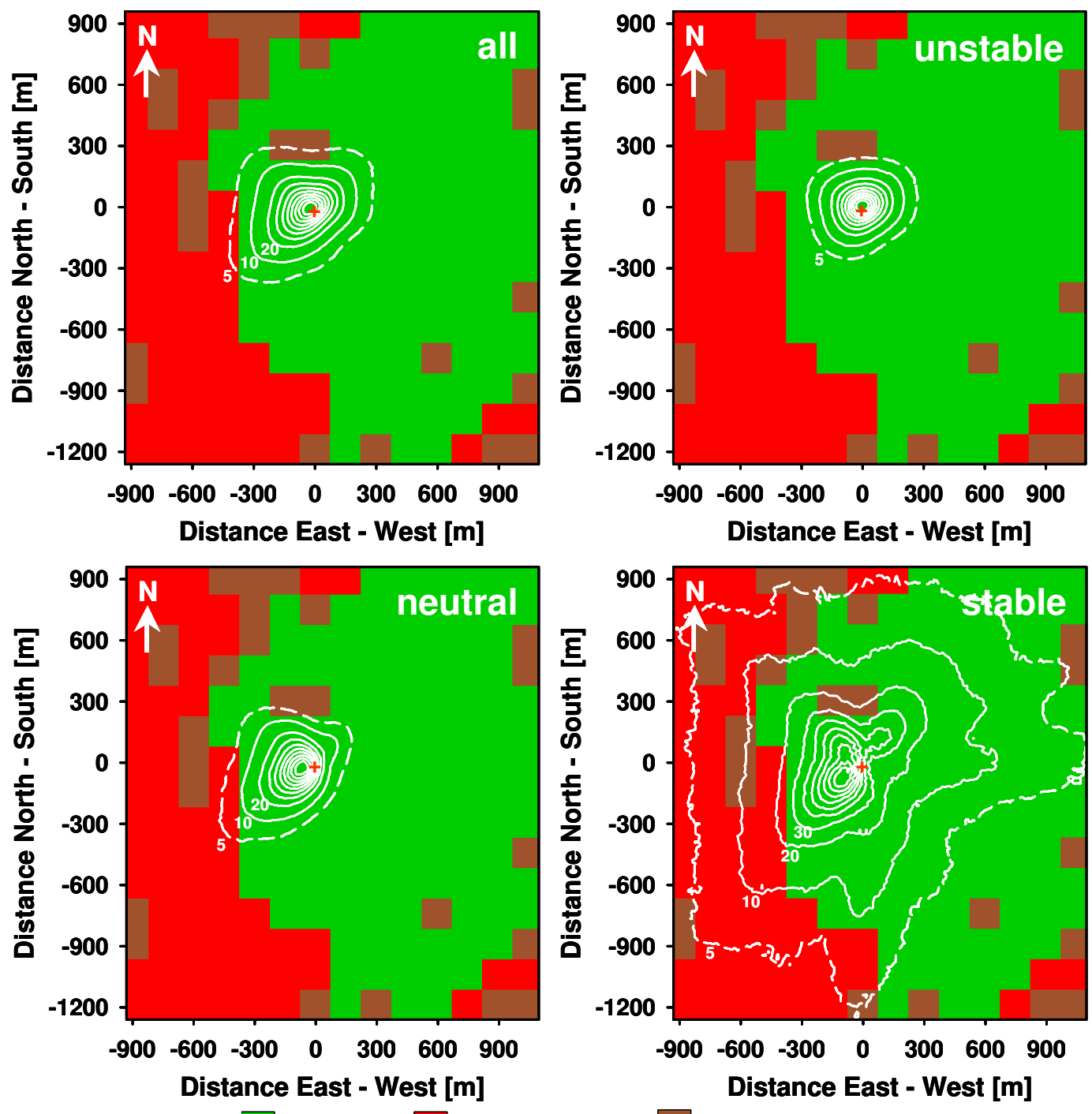

forest

settlement

Fig. 5. Footprint climatologies and land cover maps for the Brasschaat site (BE-Bra). Background colors indicate the land cover structure surrounding the tower. Panels give footprint climatologies for all cases (top left), unstable (top right), neutral (bottom left) and stable (bottom right) stratification. See legend of Fig. 1 for further map details.

Sites that have "footprint problems", i.e. a high percentage of flux contributions emitted from outside their defined target land cover type, can however be used without restrictions in applications where the exact source of the fluxes is not important. Studies like that could include for example the analysis of interannual variability, monitoring of disturbances effects, and parameterization and validation of models with a low horizontal resolution compared to the footprint of the measurements.

\subsection{Evaluation of spatial structures in flux data quality}

For a general overview of average data qualities assigned by the Foken et al. (2004) approach, Fig. 7 presents the fre- quency distributions of the median data quality found for the 25 sites involved in this study. Please note that due to software related problems, the $\mathrm{CO}_{2}$ flux for the site ES-LMa could not be evaluated in the context of this study, so only 24 sites are considered for the distributions of median data quality for $\mathrm{CO}_{2}$ in Fig. 7.

For most of the spatial maps of the momentum flux data quality, the quality ratings were in the excellent range between classes 1 and 3, indicating no significant disturbance effects on the measurements. For all sites, no significant reduction (mean QC flag greater than 6) of the data quality was observed during unstable and neutral stratification. We found isolated effects during stable stratification for three of the sites (DE-Wet, FI-Sod, PT-Mi1), and multidirectional 

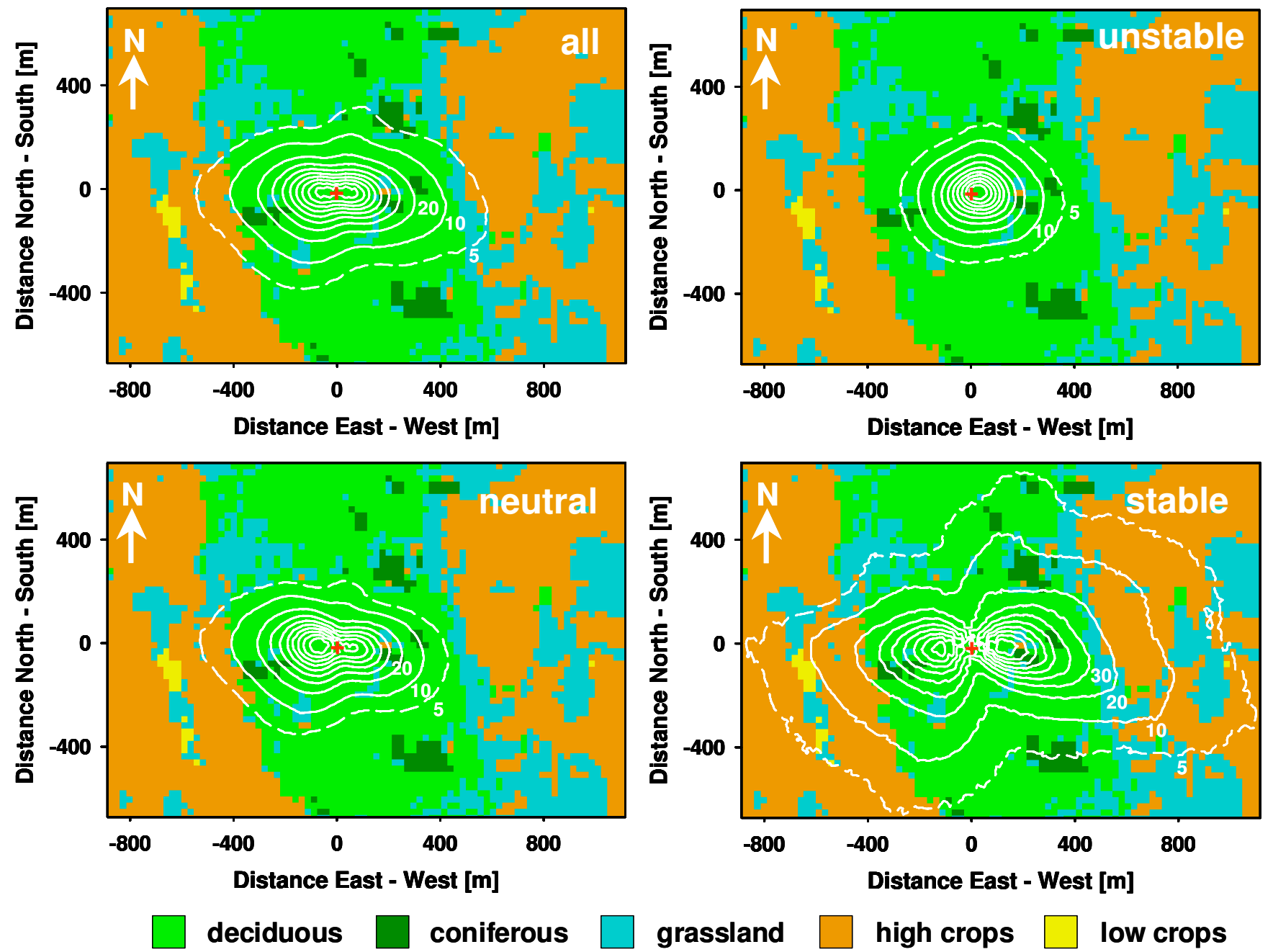

low crops

Fig. 6. Footprint climatologies and land cover maps for the Sorø site (DK-Sor). See legend of Fig. 5 for further map details.

reduction of overall data quality during stable stratification for three more sites (ES-LMa, FI-Hyy, FR-Pue).

The average data quality for the sensible heat flux was found to be lower than for the momentum flux, mainly due to a failed stationarity test for the temperature measurements. For 13 sites (BE-Bra, DE-Hai, DE-Wet, ES-LMa, FR-Hes, FR-LBr, FR-Pue, IT-Ren, IT-Ro1, IT-SRo, NL-Loo, PT-Mi1, UK-Gri), isolated effects were observed that occurred during one or two stability regimes. Since all stability regimes are affected, these effects are likely to be caused by heterogeneities in the source strength of the sensible heat flux in the surrounding area, instead of systematic errors in e.g. instrument setup, flux processing or quality flag assignment. Three more sites experienced a multidirectional reduction of the sensible heat flux data quality, two of those during stable stratification (FI-Hyy, IT-Col), and one (CH-Lae) during neutral stratification.

For the latent heat flux, overall data quality was frequently found to be only moderate (classes 3 to 6). For four sites, isolated disturbances were observed (DE-Wet, ES-LMa, FISod, IT-SRo), most of those (except IT-SRo) restricted to a single stability class. Multidirectional reduction in data quality occurred mostly during stable stratification at 11 sites (CH-Lae, CZ-BK1, DK-Sor, FI-Hyy, FR-LBr, FR-Pue, ITCol, IT-Ren, IT-Ro1, PT-Mi1, UK-Gri). For two of these sites, the data quality was significantly reduced for all stratification regimes: $\mathrm{CH}-\mathrm{Lae}$, which is situated on a mountain slope, and UK-Gri for which wintertime data were analyzed. The observed patterns suggest that reduced data quality of the latent heat flux can be attributed to a large extent to measurement problems such as water in the tubing systems of closed-path IRGAs, or open-path analyzers with liquid precipitating on the windows of the measurement path during rain or fog events, while terrain effects only play a minor role. A reduction of tubing length and regular cleaning of the tubing can help to improve the quality for closed-path systems. 

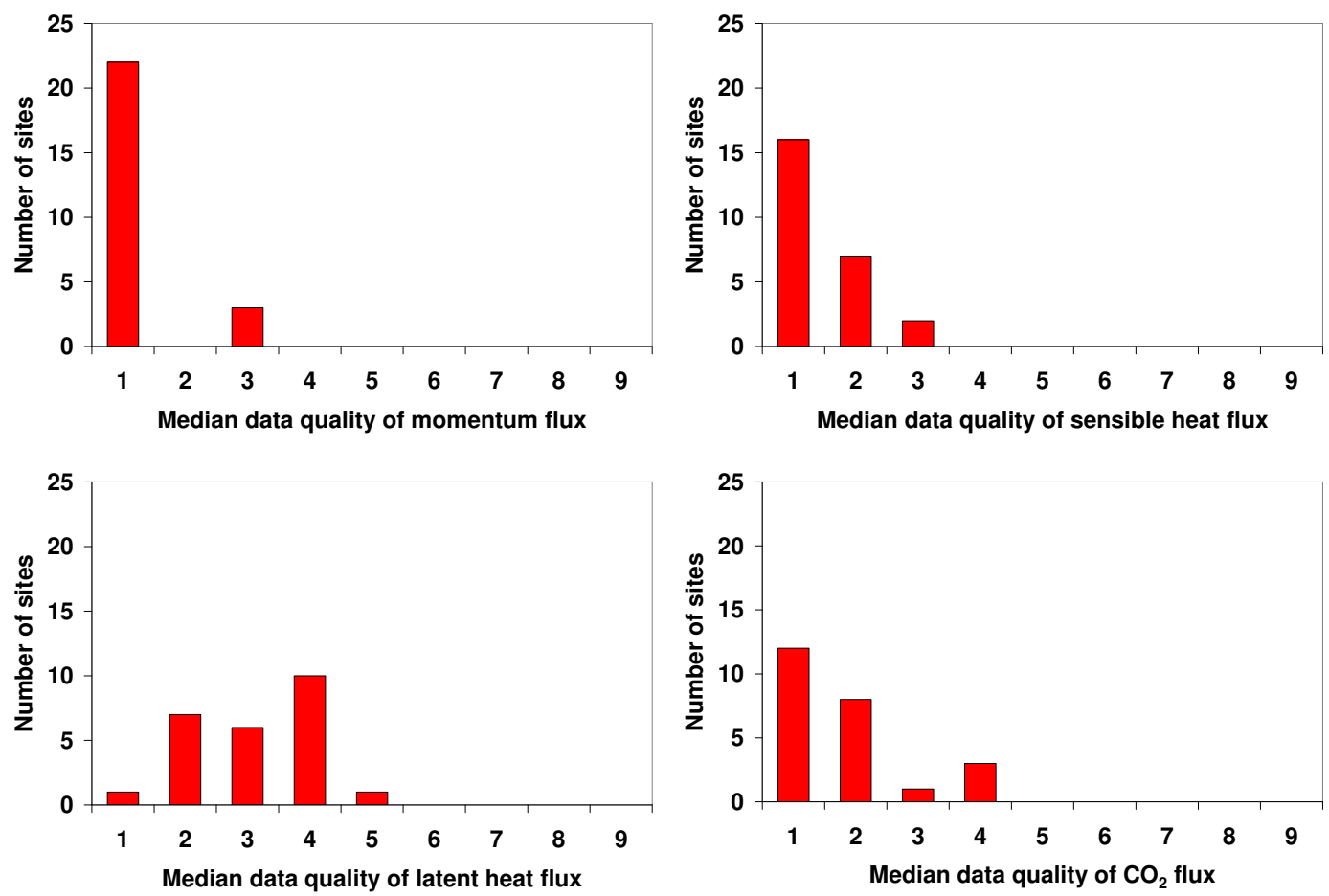

Fig. 7. Frequency distribution of the median of the data quality for four different fluxes measured at the 25 forest sites participating in this study.

Table 4. Integrated classification of spatial effects in the data quality.

\begin{tabular}{clcl}
\hline Class & Description & Number of sites & Site list \\
\hline 1 & No problems & 6 & BE-Vie, DE-Tha, DE-Wei, IL-Yat, \\
2 & Only isolated effects & 7 & $\begin{array}{l}\text { IT-PT1, PT-Esp } \\
\text { BE-Bra, DE-Hai, DE-Wet, FI-Sod, } \\
\text { FR-Hes, IT-SRo, NL-Loo }\end{array}$ \\
3 & Isolated effects and up to one multidirectional effect & 7 & CZ-BK1, DK-Sor, ES-LMa, FR-LBr, \\
4 & Several multidirectional effects & 5 & IT-Ren, IT-Ro1, UK-Gri \\
& & & CH-Lae, FI-Hyy, FR-Pue, \\
\end{tabular}

The overall data quality of the $\mathrm{CO}_{2}$ flux was mostly found to be good to very good (classes 1 to 3 ). For five sites (DE-Wet, FR-Hes, FR-LBr, IT-SRo, UK-Gri), isolated effects were detected that reduced the data quality in one or two stratification regimes. Multidirectional problems were found at three sites (CH-Lae, FI-Hyy, PT-Mi1). Possible explanations for the reduced data quality in these cases include steep topography and channeled flow (CH-Lae) or high frequency of occurrence of low turbulence intensities (FI-Hyy). As for the sensible heat flux, data quality of the $\mathrm{CO}_{2}$ flux seems to be influenced mostly by smaller scale variations of source strength in the surrounding terrain, while sensor problems play a minor role.
Instrumental effects on the spatial structures of data quality were only observed for the two sites that used METEK USA1 sonic anemometers, FI-Sod and IT-Roc (all other sites installed Gill instruments). In the case of FI-Sod, all quality maps were clearly structured into 3 sectors with 120 degrees each during stable stratification (see Fig. 1 for details), with the strongest distinction between the sectors found for latent heat flux and $\mathrm{CO}_{2}$ flux. At the IT-Roc site, the influence of the sonic structures could clearly be observed in the spatial structures of the averaged vertical wind component after applying the Planar-Fit coordinate rotation method. Both results indicate that the geometry of the METEK USA1 sensor head influences the wind field, which may have an effect on the data quality under certain conditions. The problem may 
be caused by an ineffective head correction (Mauder et al., 2007).

To facilitate a site intercomparison and overall network evaluation, the results for the four different fluxes and the instrumental effects listed above can be integrated into four major categories (Table 4).

\subsection{Results of the Planar-Fit coordinate rotation method}

The frequency distribution of the maximum value of the remaining residues after performing the rotation is displayed in Fig. 8. The results demonstrate that the application of the Planar-Fit coordinate rotation method was successful in the majority of the cases. For 20 of the 25 sites, the maximum of the residue of the mean vertical wind velocity did not exceed the threshold of $0.06 \mathrm{~m} / \mathrm{s}$. As for most of those cases the area with the maximum residue was restricted to a very small part of the terrain covered by the accumulated source weight function, the total effect of these deviations from the ideal value of zero should be insignificant for the flux processing.

For three of the sites analyzed, Planar-Fit could not provide a rotated flow field with residues low enough to be considered insignificant (vertical velocity residue $>=0.10 \mathrm{~m} \mathrm{~s}^{-1}$, CH-Lae, FR-LBr, IT-Ren), and two more sites (DE-Tha, PTMi1) were close to that threshold. In all cases, the distortion of the streamlines of the averaged flow cannot be removed with a single set of coordinate angles. For two of those sites (CH-Lae, IT-Ren), this is a consequence of complex mountainous terrain, and also for DE-Tha the curved streamlines in a narrow wind sector to the east of the tower can be attributed to the hilly topography. For FR-LBr, the distorted streamlines are caused by steep gradients in surface roughness due to a significant step change in vegetation height such as a forest edge close to the tower position. In the case of the PT-Mi1 site which is situated in rather open savanna forest, possible explanations include a distortion of the wind field by individual trees close to the tower, or a flow distortion by the inlet tube of the IRGA system which partly obstructs the sonic anemometer in the disturbed wind sectors.

\section{Discussion}

Interpretation of the results has to consider that Göckede et al. (2006) developed their site evaluation approach as a practical and easy-to-use tool that allows to conduct extensive network studies as presented in this study. With an average of close to 4000 Lagrangian Stochastic footprints to be calculated for each of the 25 participating sites, generalizations like the use of pre-calculated source weight functions had to be adopted to reduce processing time. Consequently, adapting the flow statistics for the footprint computation to specific characteristics of the individual sites was not possible in the context of this study. Since any footprint model can only be as good as the description of the underlying tur-

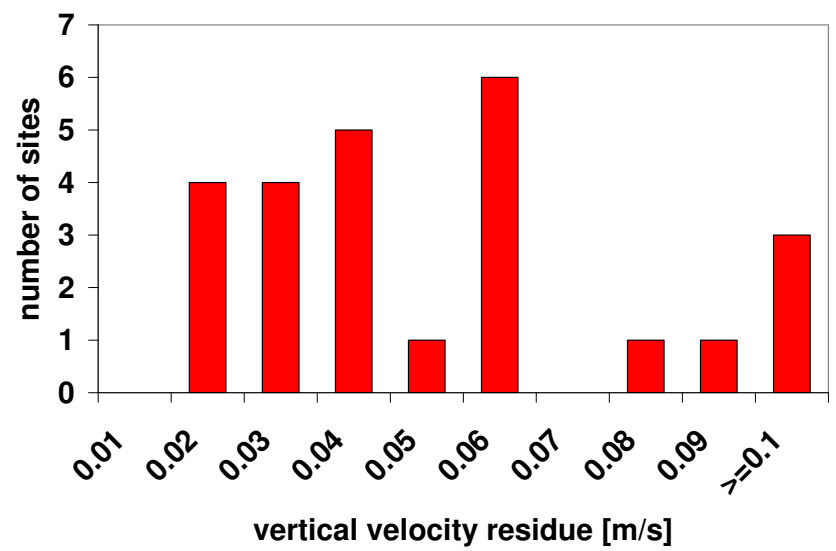

Fig. 8. Frequency of occurrence of the maximum residues of the mean vertical wind velocity after performing the Planar-Fit coordinate rotation method. Values for individual sites are included in Table 3.

bulent flow conditions, this simplification introduces additional scatter into the results (e.g. Göckede et al., 2007). The performance of footprint models is further compromised by complex topographical conditions and step changes in surface properties (e.g. Schmid and Oke, 1988; Klaassen et al., 2002; Leclerc et al., 2003; Foken and Leclerc, 2004), which alter the atmospheric flow conditions. Consequently, the applied method may introduce additional uncertainty especially at sites with fine scale heterogeneities in land cover structure, and frequent transitions from e.g. arable land to tall forest. Overall, the uncertainty introduced by the footprint modeling basically affects quantitative results like the percentage flux contributions from different types of land cover. Effects of footprint uncertainty on the predicted flux contributions depend on the relative position of heterogeneities to the tower location and on the local wind climatology, so that it is not possible to provide a general error estimate.

Releasing particles only close to the ground in the setup of the Lagrangian stochastic footprint model introduces an additional bias into the footprint computations, since the vertical structure of sources and sinks may be different for each of the fluxes (e.g. $\mathrm{CO}_{2}$ flux vs. latent heat flux), and may also change over time (e.g. daily course of $\mathrm{CO}_{2}$ assimilation in the upper canopy). Sensitivity analyses for the particle release height carried out for the same LS footprint model as applied herein (Markkanen et al., 2003; Rannik et al., 2003) demonstrate that elevated sources result in a shorter fetch and more pronounced peak of the source weight function, as compared to sources on the ground. Therefore, the footprint calculations for this study can be regarded as conservative estimates, i.e. they tend to overestimate the fetch rather than underestimate. Since for most sites the fraction of the target land cover decreases with increasing fetch distance, this implies that also the results for target area representativeness tend to be conservative. Effects on qualitative findings are expected 
to be insignificant, since the spatial maps of data quality are mainly determined by the Foken et al. (2004) quality flags for fluxes and the meteorological boundary conditions. Changing the setup of the footprint model would alter the scales of those maps, but not the spatial patterns of areas with high or low overall data quality. See Göckede et al. (2006) for a more detailed discussion.

Even though this study invested a lot of effort to assure a uniform processing of the eddy-covariance raw data of each participating site, still a site intercomparison is compromised by differences in the provided data material. We decided to rely on the experience of the cooperating research groups to pick a data set that best represents the local conditions and avoid large data gaps and/or periods with sensor malfunctions. Consequently, the provided datasets vary in length and season covered. All data were considered for this study to optimize the results for each individual site, but for site intercomparison the increased representativeness of results based on a larger dataset or the higher abundance of stable stratification cases with lower data quality during wintertime have to be considered. Also, interpretation of data quality maps such as e.g. shown in Fig. 2 must take into account that weighting according to the wind climatology is considered only for the accumulated source weight function (white lines), but not for the colored background indicating the median data quality. This implies that a sector with reduced data quality may vary in significance for the overall site evaluation, depending on whether it falls within the main wind direction or within a less frequented wind sector.

This study did not apply any kind of data filtering like use of a friction velocity threshold ( $u_{*}$ filter, e.g. Massman and Lee, 2002; $\mathrm{Gu}$ et al., 2005) to exclude situations with low turbulence intensities at nighttime, as is the normal procedure for the selection of data uploaded to the CarboEuropeIP database. Therefore, results presented herein may vary for the individual sites if the analysis was only based on submitted data, depending on the amount of data excluded by $u^{*}$ filtering. Since low data qualities are usually correlated with low turbulence intensities, application of a $u_{*}$-filter when uploading the data into the database has the potential to solve many of the data quality problems during stable stratification that are identified by the approach presented herein. However, for 17 out of the 25 sites analyzed here, the fraction of data flagged "bad" (flags in the range 7 to 9 ) was reduced by only 30 percent or less after application of a $u_{*}$-filter with a threshold as recommended by the CarboEurope database. For these sites, application of a $u_{*}$-filter would have no or very limited impact on the findings presented. Significantly better results in the maps showing spatial effects on average data quality would probably be obtained for 2 sites within this list, FI-Hyy and FR-Pue, where the fraction of bad data was reduced by more than 70 percent after application of the $u_{*}$-filter.

The different characteristics of the map material compromise a comparison between the sites, as the quality of the land cover information also influences the accuracy of the footprint analysis, and the various levels of detail may lead to biased conclusions about representativeness. For example, a forest with a large number of small scale heterogeneities such as roads and small clearings would be completely differently described by a map read out from topographical maps in a resolution of $100 \mathrm{~m}$, or produced based on remote sensing data with a resolution of $15 \mathrm{~m}$. In the former case, the implicit majority filter would make most the heterogeneities disappear, resulting in a description of a homogeneous forest, while the remote sensing map is capable to resolve the heterogeneities. On the other hand, a coarse resolution may also enhance the influence of heterogeneities which are just large enough to form the majority of a pixel, and therefore decrease the level of representativeness in the footprint analysis. Consequently, the choice of the map resolution has a significant impact on the footprint analysis, with the direction of the bias dependent on the specific land cover structure. The number of land cover types distinguished might also have a large impact on the footprint analysis, since an area with patches of different forest types might appear as homogeneous forest in a simpler map, and thus vary the target area significantly.

For the PT-Mi1 site, we ran two site analyses to highlight this aspect: The original model run was based on the land cover map with a horizontal resolution of $100 \mathrm{~m}$, which had been read out manually from topographical maps. The updated site analysis (Siebicke, 2007) used a map with $10 \mathrm{~m}$ resolution, which had been produced based on an intensive on-site vegetation survey and aerial photographs. Comparison of the maps demonstrated that, in a landscape characterized by small scale heterogeneities, a coarse resolution may significantly distort the coverage relationships between land cover types by the implicit majority filter, e.g. turning a small creek into a $100 \mathrm{~m}$ wide stream. In addition, the more realistic representation of the landscape in the high resolution map may also influence the choice of the target land cover type. In the case of PT-Mi1, the $10 \mathrm{~m}$ resolution map showed a large number of individual trees and tree groups interspersed by grass-covered areas (open savanna, or Montado), while the coarser map suggested patches of closed forest and large clearings. Regarding the Montado as the "true" target area, and use of the updated land cover map, raised the average flux contribution from the target area from $71 \%$ to $99 \%$, and consequently altered the overall site evaluation from "serious fetch problems" to "perfect fetch conditions". This example emphasizes that choice of the target area and quality of the underlying vegetation map have significant influence on the results presented by the footprint-based quality evaluation procedure presented herein, which has to be considered especially for site intercomparisons. Moreover, the approach presented only distinguishes between target area and other land cover types when assessing the representativeness of the measurements, without taking into account ecophysiological differences between the different land cover types. In 
practice, however, it will play a role if e.g. measurements intended to monitor mature forest are influenced to a certain degree by a neighboring lake or by an adjacent patch of younger forest, but the interpretation of the impact of such differences on fluxes at the individual sites is beyond the scope of this study.

Due to the sources for scatter or systematic bias listed above, the results presented herein should not be used to rank the sites of the network, or label them as suitable or unsuitable for providing valuable data for CarboEurope-IP. This study focuses on quality aspects of micrometeorological measurements, while ecological importance and available infrastructure also play a major role for site selection in a network. At sites receiving a low quality rating in one or more of the categories tested, the specific situations when data quality is significantly reduced should be closely examined, as e.g. performed by Nagy et al. (2006) at the BEBra site. Our findings highlight effects reducing data quality at individual sites as well as network-wide patterns, distinguishing between sensor related quality reductions that can be improved for and effects induced by characteristics of the surrounding terrain that have to be flagged and filtered out in the database.

Results computed with the footprint based quality assessment approach presented herein could be used to establish a network wide quality flagging procedure for eddycovariance measurements that is consistent for all sites. Uniform QA/QC flags based on objective and transparent criteria would significantly improve database reliability for a growing user community, as they allow filtering the data by criteria like momentum flux data quality or the percentage flux contribution of the specified target land cover type. Since establishment of a uniform flagging procedure is complicated due to the use of a variety of flux processing software tools in the CarboEurope-IP network, this approach could provide an alternative in the form of lookup tables which would be part of the post-processing once data got uploaded into the database. To obtain lookup tables as such, the results obtained with the approach presented would have to be binned into classes of e.g. wind direction and stability of stratification, with the number and definition of the binning parameters as well as their class definitions open to the database manager. For each combination of classes, an averaged flux contribution of the target area and a list of parameters describing expected flux data quality (e.g. median flag, or percentage of low quality measurements) can be computed. Linking those tables to the database would allow assigning additional information on data quality to each individual 30min averaged flux, allowing for users to assure the data meet the requirements for their specific studies.

\section{Summary}

This study applied the site evaluation approach by Göckede et al. (2006), which combines Lagrangian Stochastic footprint modeling with a quality assessment approach for eddycovariance data (Foken et al., 2004) to 25 forested sites of the CarboEurope-IP network. The analysis focused on the representativeness of the datasets for the specified target land cover type, spatial patterns in the data quality of momentum flux, sensible and latent heat flux and $\mathrm{CO}_{2}$ flux, the performance of the Planar-Fit coordinate rotation method (Wilczak et al., 2001), and instrumentation effects on data quality.

We did not find systematic differences in overall data quality depending on the three different types of infrared gas analyzers and four different types of sonic anemometer installed at the analyzed sites, but METEK USA1 anemometers seem to introduce spatial patterns in the data quality due to the geometry of the sensor, which may be attributed to an ineffective head correction. Most of the sites represented their specified target land cover type very well, but only ten of the 25 analyzed sites (40\%) are situated in almost homogeneous terrain, while for two sites measurements are significantly compromised by a heterogeneous land cover structure. A footprint filter is recommended as additional information in the CarboEurope-IP database to indicate level of representativeness of each stored flux measurement. 12 of the 25 sites (48\%, Table 2) experienced a significant reduction in eddycovariance data quality under certain conditions, mostly constricted to a small wind sector and a specific flux and/or atmospheric stability. Data quality was highest for momentum flux and $\mathrm{CO}_{2}$ flux. Our results indicate that the quality of the sensible heat flux was reduced mostly by terrain effects, such as small-scale heat sources that deviate significantly from their environment in terms of source strength, while instrumentation effects did not seem to be important for this parameter. For the latent heat flux, on the other hand, data quality reductions occurred due to general instrumentationrelated problem instead of effects induced by the characteristics of the surrounding terrain. The Planar-Fit coordinate rotation could be applied successfully at 20 sites, while for the remaining five sites complex mountainous terrain or significant changes in vegetation height induced a distortion of the flow field that could not be corrected for. For those sites, the use of a coordinate rotation for each averaging interval may be a more appropriate method to adapt the wind field for eddy-covariance data processing.

Overall, our quality evaluation results for the CarboEurope-IP network demonstrated a high average data quality, and good representativeness of the measurement data for the specified target land cover types. The study demonstrates that the site evaluation approach by Göckede et al. (2006), or application of footprint approaches in general, provides a valuable tool to identify measurement problems connected to terrain characteristics and instrumental setup that reduce data quality. The reliability of eddy-covariance 
databases for the user community can be significantly strengthened by using these results as part of the database, allowing to filter out and to flag data that do not meet the required standards.

Acknowledgements. This study was embedded within the framework of the European Union funded projects CARBOEUROFLUX and CARBOEUROPE-IP. Further support came from the Office of Science (BER), U.S. Department of Energy, Grant No. DE-FG0204ER63911 (AmeriFlux Measurement Network: Science Team Research).

Edited by: E. Falge

\section{References}

Amiro, B. D.: Footprint climatologies for evapotranspiration in a boreal catchment, Agr. Forest Meteorol., 90, 195-201, 1998.

Arya, S. P.: Introduction to Micrometeorology. Academic Press, San Diego, 415 pp, 2001.

Aubinet, M., Grelle, A., Ibrom, A., Rannik, Ü., Moncrieff, J., Foken, T., Kowalski, A. S., Martin, P. H., Berbigier, P., Bernhofer, C., Clement, R., Elbers, J., Granier, A., Grünwald, T., Morgenstern, K., Pilegaard, K., Rebmann, C., Snijders, W., Valentini, R., and Vesala, T.: Estimates of the annual net carbon and water exchange of forests: The EUROFLUX methodology, Adv. Ecol. Res., 30, 113-175, 2000.

Baldocchi, D., Falge, E., Gu, L. H., Olson, R., Hollinger, D., Running, S., Anthoni, P., Bernhofer, C., Davis, K., Evans, R., Fuentes, J., Goldstein, A., Katul, G., Law, B., Lee, X.H., Malhi, Y., Meyers, T., Munger, W., Oechel, W., Paw U, K. T., Pilegaard, K., Schmid, H. P., Valentini, R., Verma, S., Vesala, T., Wilson, K., and Wofsy, S.: FLUXNET: A new tool to study the temporal and spatial variability of ecosystem-scale carbon dioxide, water vapor, and energy flux densities, B. Am. Meteorol. Soc., 82, 2415-2434, 2001.

Baldocchi, D. D., Finnigan, J. J., Wilson, K., Paw U, K. T., and Falge, E.: On measuring net ecosystem carbon exchange over tall vegetation on complex terrain, Bound.-Lay. Meteorol., 96, 257-291, 2000.

Baldocchi, D. D., Krebs, T., and Leclerc, M. Y.: "Wet/dry Daisyworld": a conceptual tool for quantifying the spatial scaling of heterogeneous landscapes and its impact on the subgrid variability of energy fluxes, Tellus B, 57, 175-188, 2005.

Ciais, P., Reichstein, M., Viovy, N., Granier, A., Ogee, J., Allard, V., Aubinet, M., Buchmann, N., Bernhofer, C., Carrara, A., Chevallier, F., De Noblet, N., Friend, A. D., Friedlingstein, P., Grünwald, T., Heinesch, B., Keronen, P., Knohl, A., Krinner, G., Loustau, D., Manca, G., Matteucci, G., Miglietta, F., Ourcival, J. M., Papale, D., Pilegaard, K., Rambal, S., Seufert, G., Soussana, J. F., Sanz, M. J., Schulze, E. D., Vesala, T., and Valentini, R.: Europe-wide reduction in primary productivity caused by the heat and drought in 2003, Nature, 437, 529-533, 2005.

Dellwik, E. and Jensen, N. O.: Internal equilibrium layer growth over forest, Theor. Appl. Climatol., 66, 173-184, 2000.

Dellwik, E. and Jensen, N. O.: Flux-profile relationships over a fetch limited beech forest, Bound.-Lay. Meteorol., 115, 179-204, 2005 .
Finnigan, J. J., Clement, R., Malhi, Y., Leuning, R., and Cleugh, H. A.: A re-evaluation of long-term flux measurement techniques - Part I: Averaging and coordinate rotation, Bound.-Lay. Meteorol., 107, 1-48, 2003.

Foken, T., Skeib, G., and Richter, S. H.: Dependence of the integral turbulence characteristics on the stability of stratification and their use for Doppler-Sodar measurements, Z. Meteorol., 41, 311-315, 1991.

Foken, T. and Wichura, B.: Tools for quality assessment of surfacebased flux measurements, Agr. Forest Meteorol., 78, 83-105, 1996.

Foken, T., Göckede, M., Mauder, M., Mahrt, L., Amiro, B. D., and Munger, J. W.: Post-field data quality control, in: Handbook of Micrometeorology: A guide for Surface Flux Measurements, edited by: Lee, X., Massman, W. J., and Law, B. E., Kluwer Academic Publishers, Dordrecht, pp. 181-208, 2004.

Foken, T. and Leclerc, M. Y.: Methods and limitations in validation of footprint models, Agr. Forest Meteorol., 127, 223-234, 2004.

Foken, T.: Angewandte Meteorologie, Mikrometeorologische Methoden, (2. überarb. u. erw. Aufl.), Springer, Berlin, Heidelberg, New York, 326 pp, 2006.

Gerbig, C., Lin, J. C., Wofsy, S. C., Daube, B. C., Andrews, A. E., Stephens, B. B., Bakwin, P. S., and Grainger, C. A.: Toward constraining regional-scale fluxes of $\mathrm{CO}_{2}$ with atmospheric observations over a continent: 2. Analysis of COBRA data using a receptor-oriented framework, J. Geophys. Res.-Atmos., 108, 4757, doi:10.1029/2003JD003770, 2003.

Göckede, M., Rebmann, C., and Foken, T.: A combination of quality assessment tools for eddy covariance measurements with footprint modelling for the characterisation of complex sites, Agr. Forest Meteorol., 127, 175-188, 2004.

Göckede, M., Markkanen, T., Hasager, C. B., and Foken, T.: Update of a footprint-based approach for the characterisation of complex measurement sites, Bound.-Lay. Meteorol., 118, 635-655, 2006.

Göckede, M., Thomas, C., Markkanen, T., Mauder, M., Ruppert, J., and Foken, T.: Sensitivity of Lagrangian Stochastic footprints to turbulence statistics, Tellus B, 59, 577-586, 2007.

Gu, L., Falge, E. M., Boden, T., Baldocchi, D. D., Black, T. A., Saleska, S. R., Suni, T., Verma, S. B., Vesala, T., Wofsy, S. C., and $\mathrm{Xu}, \mathrm{L} .:$ Objective threshold determination for nighttime eddy flux filtering, Agr. Forest Meteorol., 128, 179-197, 2005.

Hasager, C. B. and Jensen, N. O.: Surface-flux aggregation in heterogeneous terrain, Q. J. Roy. Meteorol. Soc., 125, 2075-2102, 1999.

Hibbard, K. A., Law, B. E., Reichstein, M., and Sulzman, J.: An analysis of soil respiration across northern hemisphere temperate ecosystems, Biogeochemistry, 73, 29-70, 2005.

Horst, T. W. and Weil, J. C.: How far is far enough - the fetch requirements for micrometeorological measurement of surface fluxes, J. Atmos. Ocean. Tech., 11, 1018-1025, 1994.

Ibrom, A., Dellwik, E., Flyvbjerg, H., Jensen, N. O., and Pilegaard, K.: Strong low-pass filtering effects on water vapour flux measurements with closed-path eddy correlation systems, Agr. Forest Meteorol., 147, 140-156, 2007.

Jegede, O. O. and Foken, T.: A study of the internal boundary layer due to a roughness change in neutral conditions observed during the LINEX field campaigns, Theor. Appl. Climatol., 62, 31-41, 1999.

Kaimal, J. C. and Finnigan, J. J.: Atmospheric Boundary Layer 
Flows: Their Structure and Measurement, Oxford University Press, New York, 289 pp, 1994.

Kim, J., Guo, Q., Baldocchi, D. D., Leclerc, M., Xu, L., and Schmid, H. P.: Upscaling fluxes from tower to landscape: Overlaying flux footprints on high-resolution (IKONOS) images of vegetation cover, Agr. Forest Meteorol., 136, 132-146, 2006.

Klaassen, W., van Breugel, P. B., Moors, E. J., and Nieveen, J. P.: Increased heat fluxes near a forest edge, Theor. Appl. Climatol., 72, 231-243, 2002.

Kljun, N., Rotach, M. W., and Schmid, H. P.: A Three-Dimensional Backward Lagrangian Footprint Model For A Wide Range Of Boundary-Layer Stratifications, Bound.-Lay. Meteorol., 103, 205-226, 2002.

Law, B. E., Falge, E., Gu, L., Baldocchi, D. D., Bakwin, P., Berbigier, P., Davis, K., Dolman, A. J., Falk, M., Fuentes, J. D., Goldstein, A., Granier, A., Grelle, A., Hollinger, D., Janssens, I. A., Jarvis, P., Jensen, N. O., Katul, G., Malhi, Y., Matteucci, G., Meyers, T., Monson, R., Munger, W., Oechel, W., Olson, R., Pilegaard, K., Paw U, K. T., Thorgeirsson, H., Valentini, R., Verma, S., Vesala, T., Wilson, K., and Wofsy, S.: Environmental controls over carbon dioxide and water vapor exchange of terrestrial vegetation, Agr. Forest Meteorol., 113, 97-120, 2002.

Law, B. E.: Carbon dynamics in response to climate and disturbance: recent progress from multiscale measurements and modeling in AmeriFlux, in: Plant Responses to Air Pollution and Global Change, edited by: Omasa, K., Nouchi, I., and De Kok, L. J., Springer, Tokyo, pp. 205-213, 2005.

Leclerc, M. Y., Shen, S., and Lamb, B.: Observations and largeeddy simulation modeling of footprints in the lower convective boundary layer, J. Geophys. Res., 102, 9323-9334, 1997.

Leclerc, M. Y., Karipot, A., Prabha, T., Allwine, G., Lamb, B., and Gholz, H. L.: Impact of non-local advection on flux footprints over a tall forest canopy: a tracer flux experiment, Agr. Forest Meteorol., 115, 19-30, 2003.

Lee, X., Yu, Q., Sun, X., Liu, J., Min, Q., Liu, Y., and Zhang, X.: Micrometeorological fluxes under the influence of regional and local advection: a revisit, Agr. Forest Meteorol., 122, 111-124, 2004.

Liu, H. P., Peters, G., and Foken, T.: New equations for sonic temperature variance and buoyancy heat flux with an omnidirectional sonic anemometer, Bound.-Lay. Meteorol., 100, 459-468, 2001.

Markkanen, T., Rannik, Ü., Marcolla, B., Cescatti, A., and Vesala, T.: Footprints and fetches for fluxes over forest canopies with varying structure and density, Bound.-Lay. Meteorol., 106, 437459, 2003

Massman, W. J. and Lee, X.: Eddy covariance flux corrections and uncertainties in long-term studies of carbon and energy exchanges, Agr. Forest Meteorol., 113, 121-144, 2002.

Mauder, M., Liebethal, C., Göckede, M., Leps, J. P., Beyrich, F., and Foken, T.: Processing and quality control of flux data during LITFASS-2003, Bound.-Lay. Meteorol., 121, 67-88, 2006.

Mauder, M., Oncley, S. P., Vogt, R., Weidinger, T., Ribeiro, L., Bernhofer, C., Foken, T., Kohsiek, W., De Bruin, H. A. R., and Liu, H.: The energy balance experiment EBEX-2000. Part II: Intercomparison of eddy-covariance sensors and post-field data processing methods, Bound.-Lay. Meteorol., 123, 29-54, 2007.

Mauder, M., Foken, T., Bernhofer, C., Clement, R., Elbers, J., Eugster, W., Grünwald, T., Heusinkveld, B., and Kolle, O.: Quality control of CarboEurope flux data - Part 2: Inter-comparison of eddy-covariance software, Biogeosciences, 5, 451-462, 2008, http://www.biogeosciences.net/5/451/2008/.

Moore, C. J.: Frequency response corrections for eddy correlation systems, Bound.-Lay. Meteorol., 37, 17-35, 1986.

Nagy, M. T., Janssens, I. A., Curiel Yuste, J., Carrara, A., and Ceulemans, R.: Footprint-adjusted net ecosystem $\mathrm{CO}_{2}$ exchange and carbon balance components of a temperate forest, Agr. Forest Meteorol., 139, 344-360, 2006.

Obukhov, A. M.: O strukture temperaturnogo polja i polja skorostej v uslovijach konvekcii, Izv. AN SSSR, ser. Geofiz., 1392-1396, 1960.

Panin, G. N., Tetzlaff, G., and Raabe, A.: Inhomogeneity of the land surface and problems in the parameterization of surface fluxes in natural conditions, Theor. Appl. Climatol., 60, 163-178, 1998.

Panin, G. N. and Tetzlaff, G.: A measure of inhomogeneity of the land surface and parametrization of turbulent fluxes under natural conditions, Theor. Appl. Climatol., 62, 3-8, 1999.

Panofsky, H. A., Tennekes, H., Lenschow, D. H., and Wyngaard, J. C.: The characteristics of turbulent velocity components in the surface layer under convective conditions, Bound.-Lay. Meteorol., 11, 355-361, 1977.

Papale, D., Reichstein, M., Aubinet, M., Canfora, E., Bernhofer, C., Kutsch, W., Longdoz, B., Rambal, S., Valentini, R., Vesala, T., and Yakir, D.: Towards a standardized processing of Net Ecosystem Exchange measured with eddy covariance technique: algorithms and uncertainty estimation, Biogeosciences, 3, 571-583, 2006, http://www.biogeosciences.net/3/571/2006/.

Rannik, Ü., Aubinet, M., Kurbanmuradov, O., Sabelfeld, K. K., Markkanen, T., and Vesala, T.: Footprint analysis for measurements over a heterogeneous forest, Bound.-Lay. Meteorol., 97, 137-166, 2000.

Rannik, Ü., Markkanen, T., Raittila, J., Hari, P., and Vesala, T.: Turbulence statistics inside and over forest: Influence on footprint prediction, Bound.-Lay. Meteorol., 109, 163-189, 2003.

Rebmann, C., Göckede, M., Foken, T., Aubinet, M., Aurela, M., Berbigier, P., Bernhofer, C., Buchmann, N., Carrara, A., Cescatti, A., Ceulemans, R., Clement, R., Elbers, J. A., Granier, A., Grünwald, T., Guyon, D., Havrankova, K., Heinesch, B., Knohl, A., Laurila, T., Longdoz, B., Marcolla, B., Markkanen, T., Miglietta, F., Moncrieff, J., Montagnani, L., Moors, E., Nardino, M., Ourcival, J.-M., Rambal, S., Rannik, Ü., Rotenberg, E., Sedlak, P., Unterhuber, G., Vesala, T., and Yakir, D.: Quality analysis applied on eddy covariance measurements at complex forest sites using footprint modelling, Theor. Appl. Climatol., 80, 121-141, 2005.

Reichstein, M., Ciais, P., Papale, D., Valentini, R., Running, S., Viovy, N., Cramer, W., Granier, A., Ogee, J., Allard, V., Aubinet, M., Bernhofer, C., Buchmann, N., Carrara, A., Grünwald, T., Heimann, M., Heinesch, B., Knohl, A., Kutsch, W., Loustau, D., Manca, G., Matteucci, G., Miglietta, F., Ourcival, J. M., Pilegaard, K., Pumpanen, J., Rambal, S., Schaphoff, S., Seufert, G., Soussana, J. F., Sanz, M. J., Vesala, T., and Zhao, M.: Reduction of ecosystem productivity and respiration during the European summer 2003 climate anomaly: a joint flux tower, remote sensing and modelling analysis, Global Change Biol., 13, 634-651, 2007a.

Reichstein, M., Papale, D., Valentini, R., Aubinet, M., Bernhofer, C., Knohl, A., Laurila, T., Lindroth, A., Moors, E., Pilegaard, 
K., and Seufert, G.: Determinants of terrestrial ecosystem carbon balance inferred from European eddy covariance flux sites, Geophys. Res. Lett., 34, L01402, doi:10.1029/2006GL027880, $2007 b$.

Schmid, H. P. and Oke, T. R.: Estimating the source area of a turbulent flux measurement over a patchy surface, in: Proceedings of the 8th Symposium on Turbulence and Diffusion, Boston, MA, American Meteorological Society, pp. 123-126, 1988.

Schmid, H. P.: Source areas for scalars and scalar fluxes, Bound.Lay. Meteorol., 67, 293-318, 1994.

Schmid, H. P.: Experimental design for flux measurements: matching scales of observations and fluxes, Agr. Forest Meteorol., 87, 179-200, 1997.

Schmid, H. P. and Lloyd, C. R.: Spatial representativeness and the location bias of flux footprints over inhomogeneous areas, Agr. Forest Meteorol., 93, 195-209, 1999.

Schmid, H. P.: Footprint modeling for vegetation atmosphere exchange studies: a review and perspective, Agr. Forest Meteorol., 113, 159-183, 2002

Schuepp, P. H., Leclerc, M. Y., MacPherson, J. I., and Desjardins, R. L.: Footprint prediction of scalar fluxes from analytical solutions of the diffusion equation, Bound.-Lay. Meteorol., 50, 355373,1990

Siebicke, L.: Energie- und Kohlendioxidaustauschmessungen in einer Korkeichensavanne, Diploma Thesis, Department of Micrometeorology, University of Bayreuth, Bayreuth, 130 pp, 2007.

Thomas, C. and Foken, T.: Re-evaluation of Integral Turbulence Characteristics and their Parameterisations, in: Proceedings of the 15th Symposium on Boundary Layers and Turbulence, Wageningen, The Netherlands, American Meteorological Society, pp. 129-132, 2002.

Thomson, D. J.: Criteria for the selection of stochastic models of particle trajectories in turbulent flows, J. Fluid Mech., 180, 529556, 1987.

Valentini, R., Matteucci, G., Dolman, A. J., Schulze, E.-D., Rebmann, C., Moors, E. J., Granier, A., Gross, P., Jensen, N. O., Pilegaard, K., Lindroth, A., Grelle, A., Bernhofer, C., Grünwald, T., Aubinet, M., Ceulemans, R., Kowalski, A. S., Vesala, T., Rannik, Ü., Berbigier, P., Loustau, D., Guomundsson, J., Thorgeirsson, H., Ibrom, A., Morgenstern, K., Clement, R., Moncrieff, J., Montagnani, L., Minerbi, S., and Jarvis, P. G.: Respiration as the main determinant of carbon balance in European forests, Nature, $404,861-865,2000$
Wang, Y. P., Baldocchi, D., Leuning, R., Falge, E., and Vesala, T. Estimating parameters in a land-surface model by applying nonlinear inversion to eddy covariance flux measurements from eight FLUXNET sites, Global Change Biol., 13, 652-670, 2007.

Webb, E. K., Pearman, G. I., and Leuning, R.: Correction of flux measurements for density effects due to heat and water vapour transfer, Q. J. Roy. Meteorol. Soc., 106, 85-100, 1980.

Wilczak, J. M., Oncley, S. P., and Stage, S. A.: Sonic anemometer tilt correction algorithms, Bound.-Lay. Meteorol., 99, 127-150, 2001.

Wilson, J. D., Legg, B. J., and Thomson, D. J.: Calculation of particle trajectories in the presence of a gradient in turbulent-velocity variance, Bound.-Lay. Meteorol., 27, 163-169, 1983.

Wilson, J. D. and Sawford, B. L.: Review of Lagrangian stochastic models for trajectories in the turbulent atmosphere, Bound.-Lay. Meteorol., 78, 191-210, 1996.

Wilson, K. B., Baldocchi, D. D., Aubinet, M., Berbigier, P., Bernhofer, C., Dolman, H., Falge, E., Field, C., Goldstein, A., Granier, A., Grelle, A., Halldor, T., Hollinger, D., Katul, G., Law, B. E., Lindroth, A., Meyers, T., Moncrieff, J., Monson, R., Oechel, W., Tenhunen, J., Valentini, R., Verma, S., Vesala, T., and Wofsy, S.: Energy partitioning between latent and sensible heat flux during the warm season at FLUXNET sites, Water Resour. Res., 38, 1294, doi:10.1029/2001WR000989, 2002.

Wyngaard, J. C., Coté, O. R., and Izumi, Y.: Local free convection, similarity and the budgets of shear stress and heat flux, J. Atmos. Sci., 28, 1171-1182, 1971.

Yuan, W., Liu, S., Zhou, G., Zhou, G., Tieszen, L. L., Baldocchi, D., Bernhofer, C., Gholz, H., Goldstein, A. H., Goulden, M. L., Hollinger, D. Y., Hu, Y., Law, B. E., Stoy, P. C., Vesala, T., and Wofsy, S. C.: Deriving a light use efficiency model from eddy covariance flux data for predicting daily gross primary production across biomes, Agr. Forest Meteorol., 143, 189-207, 2007. 